\title{
doi.org/10.46291/ISPECIJSSHvol4iss3pp183-211
}

\section{Van İli Merkezindeki 10-12.Sınıf Öğrencilerinde Narkotik Madde Kullanım Yaygınlığg 1}

\author{
Adil YILMAYAN \\ Doktora Öğrencisi, Bakü Devlet Üniversitesi Sosyal İlimler ve Psikoloji Fakültesi, \\ adilyilmayan@hotmail.com
}

\section{Özet}

Gençlerde narkotik maddenin kullanımı ve bununla alakalı davranışlar toplumun istikbali noktasından önemsenmesi gereken toplumsal bir sorundur. Gençlik bu maddeleri denemeye kalkma noktasından en tehlikeli bir çağ olarak kabul görülmektedir. Bunun için sigara, alkol ve narkotik madde kullanımıyla alakalı çalışmaların ekserisi daha samunmasız dönem olan 'Gençlik'i merkeze almaktadırlar. Bu araştırmanın amacı, lise dönemi gençlerinde sigara, alkol ve narkotik madde kullanım yaygınlığının tesbit edilmesidir. Bu amaca yönelik, Van ili Merkezindeki 25 lisenin 10. ile 12.sınıflarında bulunan 2814 öğrenciye anket formu uygulanmış; araştırmanda madde kullanımı: lise 10.sınıf öğrencilerinde sigara $\% 13,1$, alkol \%2,7, esrar \%1,5, ekstazi \%0,7, tiner-bali \%1,5, Akineton \%0,5, kokain \%0,8, eroin $\% 0,8$, amfetamin $\% 0,5$, captagon $\% 0,5$, yeşil reçete $\% 0,6$ oranlarında; 12 .sinıf öğrencilerinde sigara \%16,1, alkol \%4,9, esrar \%2,0, ekstazi \%0,8, tiner-bali \%1,4, akineton \%0,4, kokain \%0,7, eroin $\% 0,5$, amfetamin $\% 0,4$; captagon $\% 0,4$; yeşil reçete $\% 0,5$ oranlarında olduğu tespit edilmiştir. Lise 12. sınıf öğrencilerinde lise 10. sınıf öğrencilerine kiyasla sigara, alkol ve esrar kullanım yaygınlığı anlamlı olarak daha fazladır. Erkek Öğrenciler arasındaki sigara, alkol, esrar ve diğer narkotik madde kullanım nisbetleri kızlardan anlamlı olarak daha fazladır. Araştırmaya alınan Okul Türlerindeki öğrencilerde en fazla kullanılan maddeler \%29,3'le sigara olup bunu \%7,6 alkol, \%3,6 esrar, \%2,9 tiner-bali ve \%1,5'le ekstazi izlemektedir. Verilerede yaşam boyu en az bir kere madde kullanım oranı; Fen Lisesinde en az, Anadolu Lisesinde en yüksek olduğu; Meslek Liselerinde ise, yaşam boyu en az bir kere madde kullanım oranları Anadolu Lisesinden az, Fen Lisesinden de yüksek olmasına karşılık okul türleri arasındaki oranlarda da önemli bir anlamlılık bulunmamıştır. Öğrencilerin narkotik maddeyi temin ettiği yerlere kolay ulabilirliğinin madde kullanma oranındaki yükselmede önemli bir anlamlılık görülmüştür.

Anahtar kelimeler: Lise türleri, lise öğrencileri, gençlik, madde kullanımı, narkotik madde.

\footnotetext{
${ }^{1}$ Bu makale: 2.ULUSLARARASI 23 NISAN BİLIMSEL ÇALIŞMALARKONGRESİ. 23-26 NİSAN 2020 ANKARA. kongresine sunulmuş olan "Van İli Merkez Üç İlçedeki 10-12.Sınıf Öğrencilerinde Narkotik Madde Kullanımı" başlıklı bildiriden yararlanılmış olup madde kullananların bunları temin etmedeki zorluk çekip çekmediği ile bu narkotik maddeleri temin ettikleri yer ve kişiler konusu/kısmı ilave edilmiştir.
}

Year 4/ 2020, Volume-4, Issue-3 | wWw.ispecjournal.org 


\title{
Narcotic Substance Use in 10-12th Grade Students in Three Districts of Van City Center
}

\begin{abstract}
The use of narcotic substances and related behaviors in young people is a very important social problem for the future of society. The youth is considered to be the most dangerous age from the point of experiencing narcotic substance. For this reason, the "youth", which is a more unfriendly era, focuses on the researches on cigarette, alcohol and narcotic substance use. The aim of this study is to determine the prevalence of smoking and alcohol and narcotic substance use among young people who are studying in 25 high schools 10th and 12th grades in Three Central Districts of Van city and for this purpose, the questionnaire forms were given to 2814 students in this study. In the study; In high school: 10th grade students: Smoking is $13.1 \%$, alcohol is $2.7 \%$, cannabis is $1.5 \%$, ecstasy is $0.7 \%$, thinner-bali is $1.5 \%$, Acineton is $0.5 \%$, cocaine is $0.8 \%$, heroin use $0.8 \%$, amphetamine use $0.5 \%$, captagon use $0.5 \%$, Green Prescription use rate is $0.6 \%$; In high school 12th grade students: Smoking $16.1 \%$, alcohol use $4.9 \%$, cannabis use, $2.0 \%$, ecstasy use $0.8 \%$, thinner-bali use $1.4 \%$, acineton use $0.4 \%$, cocaine use $0 \%, 7$, heroin use $0.5 \%$, amphetamine use $0.4 \%$; captagon $0.4 \%$; the use of Green Recipe was determined at the rate of $0.5 \%$. The prevalence of smoking, alcohol and cannabis use is significantly higher in high school 12th grade students compared to high school 10th grade students. Smoking, alcohol, cannabis and other narcotic substance use prevalence among boys is significantly higher than girls. - In High School Types: Substance Use Frequency Among the students, the most frequently used items are cigarettes with $29.3 \%$. This is followed by alcohol with $7.6 \%$, cannabis with $3.6 \%$, thinner-bali with $2.9 \%$ and ecstasy with $1.5 \%$. Data use rate at least once in a lifetime; It is the lowest in Science High School and the highest in Anatolian High School; In Vocational High Schools, although the substance use rates were at least once in a lifetime, it was less than Anatolian High School and higher than Science High School, but there was no significant significance among the school types. A significant significance was observed in the increase in the substance use rate of the students' availability of narcotic substance.
\end{abstract}

Keywords: High school types, high school students, youth, substance use, narcotic substance.

\section{Giriş}

Başlangıcı insanlık tarihi kadar eskilere uzanan zamanlardan beri Bağımlılık Maddelerinin kullanımı bilinmektedir. Ortadoğu'da alkollü içkilerin çeşitli türleri üretilip kullanıldığı, Çinliler esrarı 4000 sene öncesinde uzun çubuklarla içtikleri, ağrı kesici olarak Eski Mısırlılar Afyonu kullanmışlardır. İnsanlar toplu halde yaşamaya başlamasıyla ' $\dot{L} A C$ ' gayeli olarak çeşitli maddeleri kullanmışlardır. İlkel insanlar tarih öncesi dönemlerde, ağrı dindirici ve ağrı kesici olarak doğada var olan çeşitli bitkileri kullanmışlardır. Dînî âyinler ve dînî törenlerde, Year 4/ 2020, Volume-4, Issue-3 | WwW.ispecjournal.org 
çeşitli cemaatler bazı merasimlerinde zevk verici ve uyuşturucu maddeleri kullanmış oldukları görülmektedir. Narkotik maddelerin kişi üzerindeki bu enerji verici veya rahatlatıc1 etkisinden yararlanmak isteyen şahıslar uyarıcı ya da uyuşturucu olan bu Narkotik Maddeler' in kötüye kullanımına yönelerek daha fazla narkotik madde kullanmışlardır. Toplumların sosyal yapıları ve kültürüyle narkotik madde kullanımı arasında ilişkiler vardır. Muhtelif toplumlarda çeşitli keyif verici ve uyuşturucu maddeler ile ilgili olarak Alt Kültürler oluşmuştur. Bazı narkotik maddeler şahısta psikolojik bağımlılık etkisi yaparken, bazıları bireyde piskolojik ve fizikî etki yapıp adeta onu esir alıp yoksunluk hissi meydana getirirler. Bilahare şahsın ruh ve fiziksel sağglı̆ını bozan bu Maddeler, şahsı yaşayan ölü haline getirirler. Bunlar da cemiyetin genetiğine, toplumsal üretkenlik, ekonomik ve verimliliğine zararlar oluştururlar (Tuncer, 2011, s. 5; Sevil, 1998, s. 15). Esrar, afyon kokain, morfin, eroin ve psikotrop maddeler Dünyada en çok kullanılan narkotik maddelerdir. Bunların oluşturdukları alışkanlık birçok ülkede felaket seviyesine ulaşmıştır (Baygal, 2009, s. 249-285).

Narkotik madde kullanımı, bütün Dünya ve Türkiyeyi büyük bir felaket tehlikesi ile yüz yüze bırakmakta olup aynı zamanda bir bulaşıcı hastalık tarzında tüm dünyaya yayılmaktadır. Denilebilinirki, Narkotik Madde Bağımlılığı tüm dünya ülkelerinin önemle üzerinde durması gereken en birinci problemdir. Bunlara yakalanan kişi, ihtiyacı olan bir günlük dozu parasız elde etmek uğruna, bu narkotik maddelere birçok genci alıştırmaktadır. Buna yeni alışan kişiler ise, başka gençlerin -en sevdiklerini bile- narkotike alıştırmaktadırlar. Böylece bu felaket zincirinin yayılımı bütün dünyayı sarsacak şekle dönüşmektedir. Narkotik maddelerin kullanımı çok eskilerden bu yana insanların üzgünlük, pişmanlık, zaaf, umutsuzluk, acı, elem, veya neşe gibi ruhsal durumlarında narkotik maddeler ikullandıkları bilinmektedir (Akbulut, 1997, s. 111).

ABD'de her 10 kişiden biri yaklaşık 23 milyon kişi (H.Işık, s.39-55), Avrupa Birliği yetişkin nüfusunun ise neredeyse dörtte birinin, ya da 80 milyondan fazla yetişki kişinin, hayatlarının bir noktasında yasa dışı uyuşturucular kullanmış olduğu tahmini (EMCDDA, s. 40 ) göstermektedir ki, madde kullanımı ve bağımlıllğı bütün dünyada bilhassa gelişmiş olan devletlerde önemli bir halk sağlı̆ı problemi olma safhasına gelmiştir. İlaçların rasyonel olmayan ve yersiz kullanımı ve otomedikasyon gibi davranışların problem olma haline gelmesi daha ziyade gelişmekte olan ülkelerdedir. Bazı şahıslar mücadeleyi göze alamayacağı ya da aşamayacağ sorunlarla boğuşmak yerine geçici kaçışları tercihetme veya onları erteleme yoluna gitmektedir. Illaçların kötüye kullanımında ise, sağlık çalışanlarının ona kolay 
erişilebilirliği, halkın değer yargıları ve gelenekleri, bunlara dair mevzuatın toplumu etkileyip cemiyetin ilaç kullanımına karşı tutum ve davranışların şekillenmesinde mühim rol almaktadır (Dökmeci, Saltık ve Dökmeci, 1990, s. 94). Alkol kullanmada sigaranın etkili olduğu ispatlanmıştır. Literatürde, uçucu maddeler ile diğer narkotik maddelerin birbirlerinin kullanımını artırdığına ait bulgular bulunmaktadır.Narkotik Madde Kullanımı, ekseriya sigara ile başlayip sonra alkol, daha sonrasında da esrar veya bali, tiner vb. uçucular gelmektedir. Yani kişi sonraları daha ağır olan maddelere geçmektedir. Alkol ve Madde Kullanımı; son senelerde gençler arasında bu artışı hızlanmış olduğu, kullanıcı yaşlarının da gittikçe küçüldüğü ve 11-12 yaşlara düştüğü görülmektedir. Bu durumun, süreç içinde Türkiye'de de yükselişi görülmektir (Ağırakça, 2000, s. 133; Soysaldı, 2007, s. 88; Demirhan, 1999, s. 1).

Narkotik Madde Kullanımı Problemi, bireyde fizyolojik sorunlar meydana getirmekle beraber aynı zamanda ciddi psikolojik ve sosyal sorunları da birlikte getirmektedir. Bu da aileyi yıpratır ki bunlar toplumun temel taşıdır, aynı zamanda toplum içinde güvensiz ve bağımlı kişilerin ortaya çıkmasına neden olur (Evcin, 2011, s. 5-6).

Günümüzde Türkiye ve dünya narkotik madde kullanımı problemini bir gençlik problemi olarak tanımlamaktadır. Bunun için gençlik dönemi narkotik maddeyi kullanım yönünden riskli bir çağdır. Bugünkü genc içinde bulunduğu mekanlar ve etrafindaki etmenler, aile ve arkadaşların hususiyetleri ve de onun içinde vakit geçirdiği sosyal ortamlar gencin narkotik madde kullanımasını belirleyebilecek faktörler arasında yer almaktadırlar (Ögel, Ermağan, Eke, ve Taner, 2007, s. 18-23).

Endüstri ve Teknolojinin gelişmesi hem afyonu hemde yeni Narkotik Maddeleri keşfedip kullanım alanında arz ve talep dengesi meydana getirmesi, bunlardan ortaya çıkan büyük kazançlar geçmiş dönemlerde beynelmilel harblerin yaşanmasına sebep olmuştur. Aynı zamanda ticaretinin de uluslararası Narkotik Madde Kaçakçılı̆̆g'nın doğumuna neden olmuştur. Madde bağımlısı şahıslar, düzenli çalışma iktidarında olmadığından, hukuk dışı yolların her türlüsüne yeltenebilirler. Bu kişiler, maddeyi bulabilmek ya da bunun için lazım olan parayı bulabilmek adına suçların her çeşidini işlemekle beraber; şiddete başvurvurdukları, trafik kazalarına sebeb oldukları gibi muhtelif suçlarla iş ve okul yaşamlarına etkili olan olaylara da karıştıkları bilinmektedir (Ergenç ve Yıldırım, 2007, s. 13; Karataşoğlu, s. 322; Dönmezer, 1981, s. 398).

Narkotik Madde Bağımlılığının, gelişmekte olan ülkeleri daha fazla etkilediği bilinmektedir. Türkiye, gelişmekte olan bir devlet olup genç nüfusunun fazla olmasindan dolayı madde 
bağımlılığı mevzuu Türkiye açısından çok önemlidir. Araştırmalarda, madde bağımlılığının Türkiye nüfus artışı hızından daha büyük ölçüde arttığı görülmektedir (Buğdaycı, 2008, s. 1). Zamanımıza kadar, Madde Bă̆ımlılı̆̆ı, farklı maddelerin çeşitlerine göre dünyanın belirli bölgeleriyle sınırlı idi. Dünyada, kendi değerlerinden uzaklaşan ve yıkıcı bir gençlik kültürünün büyük bir hızla oluşmakta olduğu ve bunların ulusal her ortamda menfi tavırlar sergilemesi; harbler, sürat kazanan ulaşım ve değişim; kontrolsüz ve denetimsiz yapılanmalar, gençlik başta olmak üzere cemiyetin tüm kesimlerinde nice menfi tesirler oluşturmakta ve her geçen gün daha ziyade şahsı bağımlılık maddelerine yöneltip narkotik maddelerin olumsuz kullanımının her türlüsünün bütün dünyaya yayılımına neden olmaktadır (M. Işık, 2013, s. 1; Ergenç ve Y1ldırım, 2007, s. 13).

Madde'ye kolay ulaşma ve diğer risk faktörleri de eşlik ediyorsa, sigarayı deneme ile başlayan süreç bağımlılık oluşmasına kadar varır (Sadock, s. 15). Eğer bir madde o çevrede kolaylıkla bulunup elde edilebiliyorsa bu durum madde kullanımını arttıran bir faktördür. Şayet bulunulan çevrede madde yoksa onu bilme imkânı olmaz ya da tanınıp bilinse bile kullanma imkânı bulunamaz. Maddenin bulunmadığı bir yerde, madde bağımlılı̆̆ı da olmaz (Ögel, s.67).

Şurası da bilinmektedir ki, Narkotik Madde Kullanımı ekseriya arkadaş özentisi ya da merakla başlamakta ve kısa zamanda kişiyi bağımlı duruma getirmekte, arkadaş gruplarının tesiriyle de yaygınlık kazanmaktadır. Birey için adölesan çağda arkadaşların önemi büyük olması hesabiyle, bağımlılık maddeler'inin kullanımı noktasından ortaöğrenim gençliği en riskli olan gruptur. Araştırmalar, aile içinde böylesi maddeler'in kullanımı, onları örnek alan gençlerin bunlara olan yönelimi arttırmaktadır. Narkotik madde kullanımında giderek dozların arttırılması bir çok şahsın hayatına mal olmaktadır.

Toplumda Narkotik Madde Konusununun konuşulmaması ve tartışılmaması, bu gerçeğin ülke noktasında önemli bir problem olma olgusunu değiştirmediği gibi, gelecekte telafisi imkansız olan badirelere de yol açabilecektir.

$\mathrm{Bu}$ araştırmamızda, araştırma evreninde olan lise 10. ile 12.sınıflarda eğitim gören gençlerde sosyal bir sorun olan sigara, alkol ve narkotik madde kullanımı yaygınlığının tespiti, çalışmanın verileriyle de konuyla ilgili kurum ve kuruluşlara bilgi sunulması amaçlanmıştır. 


\section{Yöntem}

$\mathrm{Bu}$ çalışma kesitsel araştırma metoduyla Van Merkezinde bulunan 25 lisedeki öğrencileri Narkotik Madde Kullanımı ve Problemi yaygınlığının belirlenmesine yönelik 2015-2016 yılı ikinci yarıyıl döneminde 10. ile 12.sınıf öğrencilerine ders saatleri esnasında gönüllülük esasına dayalı anket formları dağıtılarak anket uygulanmıştır. Uygulanan bu anket formu, Trakya Üniversitesi Tıp Fakültesinde benzer bir çalışmada daha önce kullanılmış olan anket formlarından uyarlanıp kullanılmıştır. Van Valiliği ve İl Milli Eğitim Müdürlüğünün İlgili Komisyonunun onay ve desteği alınmasından sonra Van İl Merkezinde uygulanmıştır. Çalışmada, anket uygulaması yoluyla toplanmış verilerle araştırma evrenimizin Narkotik Madde Bağımlılığı konusunun tasviri yapılmaktadır.

Araştırmanın Örneklemi olan Van İl Merkezinde bulunan 64 Lisenin tüm 10. ile 12.sınıf öğrencilerinin toplam sayısı: 15.778 kişidir. Bunlardan 25 Lisedeki 10. ile 12.sınıf öğrencilerinden oluşan toplam 7949 kişisi uygulamaya alınmıştır. Bu sayı ise, 64 Lisedeki tüm 10. ile 12.sınıf öğrenci sayısının tümünün \%50.4'ünü oluştur. Belirlenmiş örneklemin büyüklüğü için 2500 öğrenci seçilmiş, bu sayı ise Van İl Merkezindeki 64 Lise 10. ile 12.sınıf tüm öğrenci sayısının \%15,8'i oranıdır. Bu örneklem büyüklüğüyle, \%1 ile \%50’ye kadar olan sıklıklar kabul edilebilir kesinlik sınırları içinde bulunmaktadır (power \%90, tahmin edilen kesinlik sınırı \%1'den \%50’ye \pm 5 ). Öğrencilerden bazılarının cevablamama, yanlış doldurma ya da öğrenci sayısının beklenenden az olması gibi faktörlerin \%15 civarında olacağı tahmininde bulunulmuş olunması, bu oran kabullenilebilir bir sıklığg işaret etmek hesabiyle toplam örneklem büyüklüğü 3000 kişi olarak belirlenmişdir. Örneklemin seçiminde, çok basamaklı küme örnekleme yöntemi kullanılmıştır (Ögel, Taner ve Eke, 2006, s. 19).

Küme örnekleminin teşkili için; ilk aşamada, Van İl Merkezinde, “TEOG 2015-2016 Taban Puanlarına Göre" 'Yükssek- Orta- Düşük Puan düzeyler'inde yer alan lise ve öğrenci sayısına göre gruplar (kümeler) listelendi; örnekleme alınacak lise sayısı olarak tabakalı örnekleme yöntemiyle 25 okul seçildi.

Her lisenin 10. ile 12. sınıf öğrenci sayılarının ağırlığına göre, o liselerde araştırmaya katılacak öğrenci sayısı belirlendi. İl Merkezinde yer alan Genel (Genel- Anadolu- Fen) Liseler ile Meslek (Endüstri- İmam Hatip- Güzel Sanatlar ve Spor) Liselerindeki tüm derslikler içinden 'Sistematik Random Yöntemi'yle kura çekilerek derslikler belirlenmiştir. Çalışmanın yapıldığı gün seçilen bu sınıflarda bulunan kız- erkek tüm öğrencilere Anket uygulanmış olup o gün okula gelmemiş olan öğrencilere tekraren anket uygulanmamıştır.

Year 4/ 2020, Volume-4, Issue-3 | www.ispecjournal.org 
Araştırmada, Van İli Merkezinde bulunan liselerden: Meslek Lisesi, Anadolu Lisesi ve Fen Lisesi'nden oluşan 3 tür(kategori) 25 lisedeki 133 derslik(57 derslik 10.sınıf - 76 derslik 12. sınıf)te anket uygulandı. Örneklemin 3000 anketinden: 2925 adedi uygulanabilmiş, 75 adedi ise uygulanamamıştır. 86 adet anket soruları cevapsız bırakılmış veya yanlış doldurulmuş, 25 kişi ise tuzak soru maddesi olan 'Zopinol'u işaretlemiş olmasından toplam 186 anket (\%3.7) değerlendirilememiştir. Böylece, ankete katılan 2925 lise öğrencisinden 2814'ünden elde edilen anket sonuçları değerlendirmeye alınmıştır. Toplam 111 öğrencinin anketi geçersiz sayılarak çalışma dışı kalmıştır.

Çalışmada kullanılan anket formu: Seçilmiş 12 maddesi narkotiğe dair olak üzere, toplam 37 bölümden oluşmaktadır. Anket formunda: Yaş, cinsiyet, ders başarısı, yaşam koşulları, ekonomik ve sosyokültürel düzeyleri ve madde kullanım sıklığı sorgulanmaktadır.

Araştırma, 2016-Mart'1nda bizzat araştırmacı tarafından yürütülmüştür. Anketler, araştırmacı ile Milli Eğitim Müdürlüğünce görevlendirilen 28 rehber öğretmenin anketörlüğünde yapılmıştır. Uygulama esnasında güvenilirliği arttırmak amacıyla Araştırmacı ve Rehber Öğretmenler dışında sınıf öğretmenlerinin sınıfta bulunmamasına dikkat edilmiştir. Uygulamaya katılan öğrencilere bilgilerinin gizli tutulacağı bildirilmiş, anketleri isimsiz doldurulması söylenmiş, anketler karışık şekilde kapalı bir zarf içinde toplanmış, anketörler anketin yapıldı̆̆ı günün sınıf mevcudunu kaydetmişlerdir. Ankette yer alan sorulara frekans ve yüzdelik tablosu oluşturulmuştur. Kullanım sıklığı, vs.bakımından gruplar arasında önemli fark olup olmadığı Ki-Kare Testi ile araştırılmıştır (Büyüköztürk vd., 2014, s. 80-100; Ögel, Tamar ve Çakmak, 1998, s. 90; Ögel, Taner ve Eke, 2006, s. 19).

Anketlerden elde edilen veriler, "SPSS 22.0 Paket Programı" ile istatistikî değerlendirmesi yapılmış, tanımlayıcı analizler için ise "Ki-Kare (Pearson Chi-Square) İstatistik Testi" kullanılmıştır. Bütün istatistikler için anlamlılık sınırı $\mathrm{p}<0,05$ olarak kabul edilmiştir (Balcı, 2015, s. 260-274; Asan, Göka, Okay ve T1kır, 2015, s. 3).

$\mathrm{Bu}$ çalışmada anket yardımıyla toplanan verilerle araştırma evreninin narkotik madde kullanımı konusunda betimleme yapılarak öğrencilerde sigara, alkol ve madde kullanımının yaygınlığının tespiti ile kişinin narkotik madde kullanımı ilişkilerinin incelenmesi yapıldı.

\subsection{Araştırmanın Önemi}

Bu çalışmada Van il Merkezindeki 10. ile 12. sınıf öğrencilerinin bağımlılık yapıcı narkotik madde kullanım yaygınlığı ile lise türleri öğrencileri arasındaki madde kullanım düzeyleri 
araştırılmıştır. Araştırmada tüm örneklem evreninin (64 lise öğrencilerinin) \%15,8'inin, örneklemin (25 lise öğrencilerinin) ise \% 50,4'ünün uygulamaya alınmış olması; çalış1lan örneklemin evreni temsil gücü ve tahmin gücü bakımından yüksektir.

Bu araştırma Van Il Merkezini temsil eder mahiyette ilk ve tek olan kapsamlı madde kullanımı yaygınlık araştırmasıdır. Bu araştırmada, Van İl Merkezî lise öğrencilerinin sigara, alkol ve narkotik narkotik madde kullanım durumlarının ortaya konulmasıyla; her geçen gün artış gösteren narkotik madde kullanımı ile mücadele eden kurum ve kuruluşlara bilgi sunulmaktadır.

\subsection{Sinırlılıklar:}

Araştırılan konunun zorluğu, madde kullanımının ortaya çıkması durumunda kişinin aile ve çevresiyle çatışma içine girme ihtimali, çıkabilecek hukuki problemler, endişe ve korkular vb. durumların neden olacağı olumsuzluklar, geçersiz ve yanlış veri elde etme ihtimalinin yüksek olacağı; toplumumuzda madde kullanımı ve bağımlılığı, üzerinde konuşulmak istenmeyen bir durum olmanın yanında; akademisyen ve devlet görevlilerinin de uzak durmaya çalıştıkları bir konu şeklinde karşımıza çıkmakta olduğu; bazı kesimlerce narkotik madde konusunda konuşmanın dahi gençlere özendirici olacağına dair inancın olması; Narkotik Madde kullanımına dair herhangi bir anket uygulamasında bireylerin ve İlgililerin bundan rahatsızlık hissetmeleri ya da bazen reddetmeleri, bu mevzuda yapılan çalışmaların önündeki en önemli engellerdendir.

\subsection{Sayıltılar}

Genel olarak: Bireyylerin yöneltilen suallere verdiği cevabların doğruluğunun kabulü; gençlerin narkotik madde kullanımıyla ilgili bu tespit ölçeği anketini gerçeğe uygun olarak dolduracakları; çalışmada belirlenen yöntem ve veri toplama tekniklerinin araştırmaya uygunluğu, varsayılmıştır.

\section{Bulgular ve Analiz}

Araştırmaya katılan 2814 öğrenciden 36 kişi (\%1.3) cinsiyet bölümü işaretlememiştir. Geri kalan 2778 öğrenciden 1374'i erkek (\%49.5), 1404’ü kadın(\%50.5)dan oluşmaktadır. Bu da Türkiye İstatistik Kurumu 2015 verileriyle (Erkek \%50,2 - kadın \%49,8) az bir farkla 
örtüşmektedir (TÜIKK, 2015). Anket Formunun 27.Maddesinde sorgulanmış olan "12 madde'nin hepsi bu çalışmada 'Narkotik Madde"” olarak değerlendirilmiştir (Tablo 1).

Tablo 1: Lise öğrencilerinde cinsiyete göre dağılım oranları

\begin{tabular}{|c|c|c|c|c|}
\hline CINSIYYET & $\mathbf{f}$ & $\%$ & Toplam f (\%) & $\mathbf{p}$ \\
\hline Erkek & 1374 & $\% 49.5$ & 2778 & \\
\hline Kadın & 1404 & $\% 50.5$ & $\% 100$ & $\mathbf{0 , 0 0 0}$ \\
\hline
\end{tabular}

Ankete katılan lise öğrencilerinden 36 kişi narkotik madde bölümünü işaretlemeyip cinsiyete göre en az bir kere madde kullanımı bölümünü işaretleyenler toplam 2778 kişidir. Bunların 552'si erkek (\%19.9), 294'ü kadın (\%10.6) oranlarında olup bunların toplam 846 kişi olarak bulunmuştur (Tablo 2).

Tablo 2: Lise öğrencilerinde cinsiyete göre madde kullanım oranları

\begin{tabular}{|c|c|c|c|c|c|c|c|}
\hline \multirow{3}{*}{ CINSSIYET } & \multicolumn{7}{|c|}{ MADDE KULLANMA } \\
\hline & \multicolumn{2}{|c|}{ EVET } & \multicolumn{2}{|c|}{ HAYIR } & \multicolumn{2}{|c|}{ TOPLAM } & \multirow{2}{*}{$\mathbf{p}$} \\
\hline & f & $\%$ & f & $\%$ & f & $\%$ & \\
\hline Erkek & 552 & 40,2 & 822 & 59,8 & 1374 & 100 & \multirow{3}{*}{0,000} \\
\hline Kadın & 294 & 20,9 & 1110 & 79,1 & 1404 & 100 & \\
\hline Toplam & 846 & 30,5 & 1932 & 69,5 & 2778 & 100 & \\
\hline
\end{tabular}

Tablo 1, 2, 3, 4, 5'e bakıldığında: 1374 erkekten 552 kişi(\% 40,2)'si, 1403 kadından ise 294 kişi(\%20,9)'si madde kullandığını belirtmiştir. Burada, erkeklerin narkotik madde kullanım oranları kadınların madde kullanım oranlarından anlamlı derecede daha yüksektir $(p=0,000)$ (Tablo 1, 2, 3, 4, 5).

Tablo 3: Lise öğrencilerinde madde kullanım oranlarının cinsiyete göre dağılımı

\begin{tabular}{|c|c|c|c|c|c|c|c|c|c|}
\hline \multirow{2}{*}{$\begin{array}{l}\text { KULLANI- } \\
\text { LAN } \\
\text { MAD- } \\
\text { DELER }\end{array}$} & \multicolumn{3}{|c|}{ ERKEK } & \multicolumn{3}{|c|}{ KADIN } & \multirow{2}{*}{\multicolumn{2}{|c|}{$\begin{array}{l}\text { TOPLAM } \\
\text { f }(\%)\end{array}$}} & \multirow[b]{2}{*}{$\mathbf{p}$} \\
\hline & $\begin{array}{l}\text { Evet } \\
\text { f (\%) }\end{array}$ & $\begin{array}{l}\text { Hayır } \\
\text { f }(\%)\end{array}$ & $\begin{array}{l}\text { Toplam } \\
\text { f }(\%)\end{array}$ & $\begin{array}{l}\text { Evet } \\
\text { f }(\%)\end{array}$ & $\begin{array}{l}\text { Hayır } \\
\text { f }(\%)\end{array}$ & $\begin{array}{l}\text { Toplam } \\
\text { f }(\%)\end{array}$ & & & \\
\hline Sigara & $\begin{array}{l}532 \\
(38,7)\end{array}$ & $\begin{array}{l}842 \\
(61,3)\end{array}$ & $\begin{array}{l}\mathbf{1 3 7 4} \\
(100)\end{array}$ & $\begin{array}{l}281 \\
(20,0)\end{array}$ & $\begin{array}{l}1122 \\
(80,0)\end{array}$ & $\begin{array}{l}\mathbf{1 4 0 3} \\
(100,0)\end{array}$ & $\begin{array}{l}\mathbf{8 1 3} \\
(29,3)\end{array}$ & $\begin{array}{l}\mathbf{2 7 7 8} \\
(100)\end{array}$ & $\mathbf{0 , 0 0 0}$ \\
\hline Alkol & $\begin{array}{l}158 \\
(11,5)\end{array}$ & $\begin{array}{l}1214 \\
(88,5)\end{array}$ & $\begin{array}{l}\mathbf{1 3 7 2} \\
(100)\end{array}$ & $\begin{array}{l}51 \\
(3,6)\end{array}$ & $\begin{array}{l}1352 \\
(96,4)\end{array}$ & $\begin{array}{l}\mathbf{1 4 0 3} \\
(100,0)\end{array}$ & $\begin{array}{l}209 \\
(7,5)\end{array}$ & $\begin{array}{l}2776 \\
(100)\end{array}$ & 0,000 \\
\hline Esrar & 85 & 1289 & 1374 & 14 & 1389 & 1403 & 99 & 2778 & 0,000 \\
\hline
\end{tabular}




\begin{tabular}{|c|c|c|c|c|c|c|c|c|c|}
\hline & $(6,2)$ & $(93,8 \%)$ & (100) & $(1,0)$ & (99) & $(100,0)$ & $(3,6)$ & $\begin{array}{l}(100) \\
\end{array}$ & \\
\hline Ekstazi & $\begin{array}{l}35 \\
(2,5)\end{array}$ & $\begin{array}{l}1339 \\
(97,5)\end{array}$ & $\begin{array}{l}\mathbf{1 3 7 4} \\
(100)\end{array}$ & $\begin{array}{l}7 \\
(0,5)\end{array}$ & $\begin{array}{l}1396 \\
(99,5)\end{array}$ & $\begin{array}{l}\mathbf{1 4 0 3} \\
(100,0)\end{array}$ & $\begin{array}{l}\mathbf{4 2} \\
(1,5)\end{array}$ & $\begin{array}{l}\mathbf{2 7 7 8} \\
(100)\end{array}$ & $\mathbf{0 , 0 0 0}$ \\
\hline Tiner -Bali & $\begin{array}{l}64 \\
(4,7)\end{array}$ & $\begin{array}{l}1310 \\
(95,3)\end{array}$ & $\begin{array}{l}\mathbf{1 3 7 4} \\
(100)\end{array}$ & $\begin{array}{l}16 \\
(1,1)\end{array}$ & $\begin{array}{l}1387 \\
(98,9)\end{array}$ & $\begin{array}{l}\mathbf{1 4 0 3} \\
(100,0)\end{array}$ & $\begin{array}{l}\mathbf{8 0} \\
(2,9)\end{array}$ & $\begin{array}{l}\mathbf{2 7 7 8} \\
(100)\end{array}$ & $\mathbf{0 , 0 0 0}$ \\
\hline Akineton & $\begin{array}{l}21 \\
(1,5)\end{array}$ & $\begin{array}{l}1353 \\
(98,5)\end{array}$ & $\begin{array}{l}\mathbf{1 3 7 4} \\
(100)\end{array}$ & $\begin{array}{l}4 \\
(0,3)\end{array}$ & $\begin{array}{l}1399 \\
(99,7)\end{array}$ & $\begin{array}{l}1403 \\
(100,0)\end{array}$ & $\begin{array}{l}\mathbf{2 5} \\
(0,9)\end{array}$ & $\begin{array}{r}2778 \\
(100)\end{array}$ & 0,001 \\
\hline Kokain & $\begin{array}{l}31 \\
(2,3)\end{array}$ & $\begin{array}{c}1343 \\
(97,7)\end{array}$ & $\begin{array}{l}\mathbf{1 3 7 4} \\
(100)\end{array}$ & $\begin{array}{l}9 \\
(0,6)\end{array}$ & $\begin{array}{l}1394 \\
(99,4)\end{array}$ & $\begin{array}{l}\mathbf{1 4 0 3} \\
(100,0)\end{array}$ & $\begin{array}{l}\mathbf{4 0} \\
(1,4)\end{array}$ & $\begin{array}{l}2778 \\
(100)\end{array}$ & 0,000 \\
\hline Eroin & $27(2,0)$ & $\begin{array}{l}1347 \\
(98,0)\end{array}$ & $\begin{array}{l}\mathbf{1 3 7 4} \\
(100)\end{array}$ & $\begin{array}{l}8 \\
(0,6)\end{array}$ & $\begin{array}{l}13965 \\
(99,4)\end{array}$ & $\begin{array}{l}1403 \\
(100,0)\end{array}$ & $\begin{array}{l}\mathbf{3 5} \\
(1,3)\end{array}$ & $\begin{array}{l}\mathbf{2 7 7 8} \\
(100)\end{array}$ & 0,001 \\
\hline Amfetamin & $20(1,5)$ & $\begin{array}{l}1354 \\
(98,5)\end{array}$ & $\begin{array}{l}1374 \\
(100)\end{array}$ & $\begin{array}{l}4 \\
(0,3)\end{array}$ & $\begin{array}{l}1399 \\
(99,7)\end{array}$ & $\begin{array}{l}1403 \\
(100,0)\end{array}$ & $\begin{array}{l}24 \\
(0.9)\end{array}$ & $\begin{array}{r}2778 \\
(100)\end{array}$ & 0,001 \\
\hline Captagon & $19(1,4)$ & $\begin{array}{l}1355 \\
(98,6)\end{array}$ & $\begin{array}{l}\mathbf{1 3 7 4} \\
(100)\end{array}$ & $\begin{array}{l}5 \\
(0,4)\end{array}$ & $\begin{array}{l}1398 \\
(99,6)\end{array}$ & $\begin{array}{l}\mathbf{1 4 0 3} \\
(100,0)\end{array}$ & $\begin{array}{l}24 \\
(0,9)\end{array}$ & $\begin{array}{l}2778 \\
(100)\end{array}$ & 0,003 \\
\hline $\begin{array}{l}\text { Yeşil } \\
\text { Reçete }\end{array}$ & $26(1,9)$ & $\begin{array}{l}1348 \\
(98,1)\end{array}$ & $\begin{array}{l}\mathbf{1 3 7 4} \\
(100)\end{array}$ & $\begin{array}{l}5 \\
(0,4)\end{array}$ & $\begin{array}{l}1398 \\
(99,6)\end{array}$ & $\begin{array}{l}\mathbf{1 4 0 3} \\
(100,0)\end{array}$ & $\begin{array}{l}\mathbf{3 1} \\
(1,1)\end{array}$ & $\begin{array}{l}2778 \\
(100)\end{array}$ & $\mathbf{0 , 0 0 0}$ \\
\hline Diğer & $17(1,2)$ & $\begin{array}{l}1357 \\
(98,8)\end{array}$ & $\begin{array}{l}\mathbf{1 3 7 4} \\
(100)\end{array}$ & $\begin{array}{l}3 \\
(0,2)\end{array}$ & $\begin{array}{l}1400 \\
(99,8)\end{array}$ & $\begin{array}{l}1403 \\
(100,0)\end{array}$ & $\begin{array}{l}\mathbf{2 0} \\
(0,7)\end{array}$ & $\begin{array}{l}2778 \\
(100)\end{array}$ & 0,001 \\
\hline
\end{tabular}

Tablo 4: Lise Erkek öğrencilerinde madde kullanım oranları dağılımı

\begin{tabular}{|c|c|c|c|c|c|}
\hline \multirow{3}{*}{$\begin{array}{l}\text { KULLANILAN } \\
\text { MADDELER }\end{array}$} & \multicolumn{3}{|c|}{ ERKEK ÖĞRENCİLERINIIN MADDE KULLANIMI } & \multirow{3}{*}{$\begin{array}{l}\text { TOPLAM } \\
\text { f }(\%)\end{array}$} & \\
\hline & Evet & Hayır & Toplam & & \\
\hline & $\mathbf{f}(\%)$ & $\mathbf{f}(\%)$ & $\mathbf{f}(\%)$ & & \\
\hline Sigara & $532(38,7)$ & $842(61,3)$ & 1374(100) & $\mathbf{5 3 2}(19,2)$ & 2778(100) \\
\hline Alkol & $158(11,5)$ & $1214(88,5)$ & 1372(100) & $158(5,7)$ & 2776(100) \\
\hline Esrar & $85(6,2)$ & $1289(93,8 \%)$ & 1374(100) & $\mathbf{8 5}(3,1)$ & 2778(100) \\
\hline Ekstazi & $35(2,5)$ & $1339(97,5)$ & 1374(100) & $35(1,3)$ & 2778(100) \\
\hline Tiner -Bali & $64(4,7)$ & $1310(95,3)$ & $1374(100)$ & $64(2,3)$ & 2778(100) \\
\hline Akineton & $21(1,5)$ & $1353(98,5)$ & $1374(100)$ & $21(0,8)$ & 2778(100) \\
\hline Kokain & $31(2,3)$ & $1343(97,7)$ & $1374(100)$ & $31(1,1)$ & 2778(100) \\
\hline Eroin & $27(2,0)$ & $1347(98,0)$ & $1374(100)$ & $27(1,0)$ & 2778(100) \\
\hline Amfetamin & $20(1,5)$ & $1354(98,5)$ & $1374(100)$ & $20(0,7)$ & 2778(100) \\
\hline Captagon & $19(1,4)$ & $1355(98,6)$ & $1374(100)$ & $19(0,7)$ & 2778(100) \\
\hline Yeşil Reçete & $26(1,9)$ & $1348(98,1)$ & $1374(100)$ & $26(0,9)$ & 2778(100) \\
\hline Diğer & $17(1,2)$ & $1357(98,8)$ & $1374(100)$ & $17(0,6)$ & 2778(100) \\
\hline
\end{tabular}


Tablo 5: Lise Kadın öğrencilerinde madde kullanım oranları dağılımı

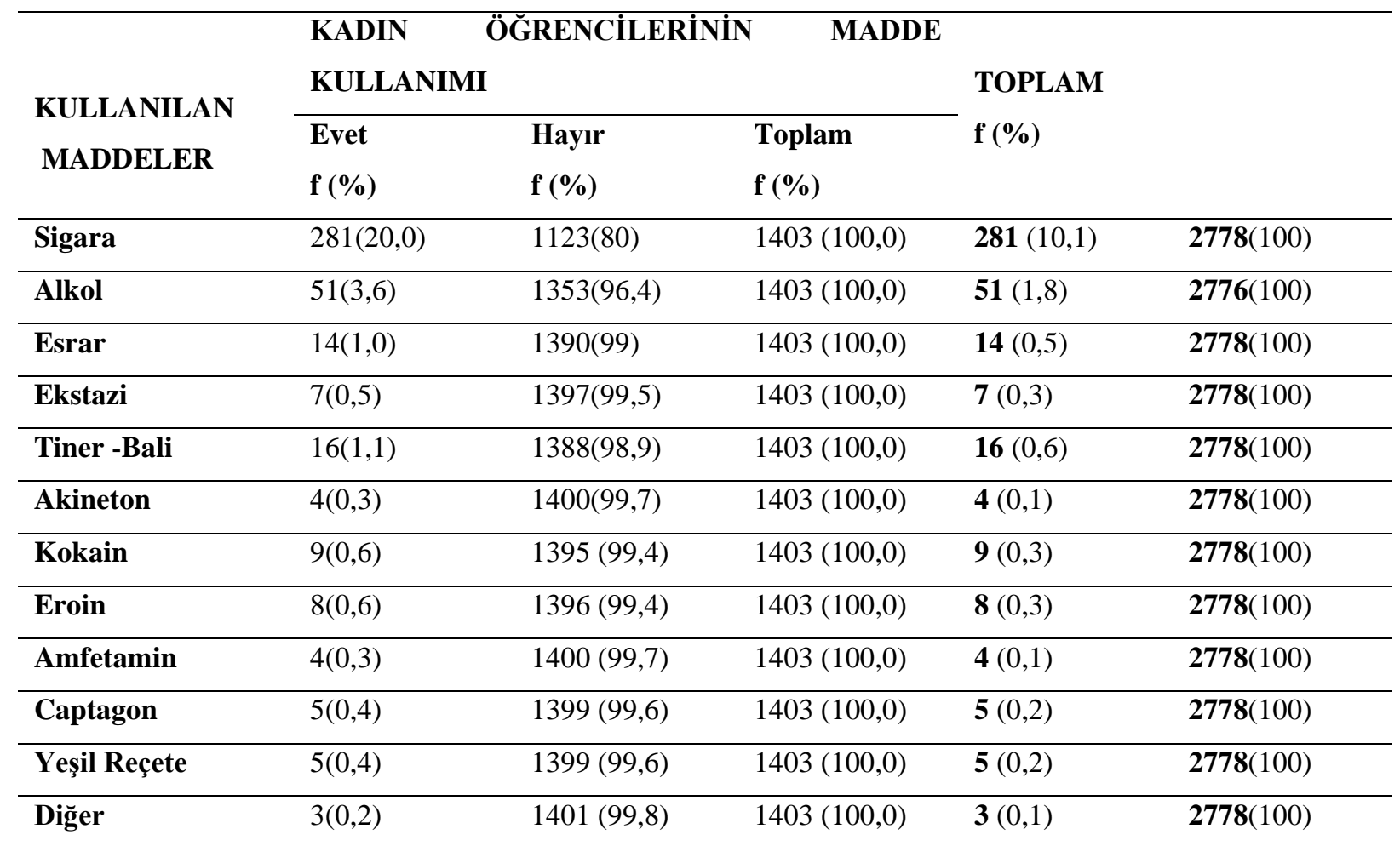

Öğrencilerden hayatında en az bir kere madde kullandığını belirten \%30,5 (858 kişi), kullanmadığını belirten \%69,5 (1956 kişi) olarak belirlenmiştir (Tablo 6).

Tablo 6: Yaşam boyu tüm lise öğrencilerinde en az bir kere madde kullanımına işaretleyenlere göre madde kullanım oranları

\begin{tabular}{|c|c|c|c|c|c|c|c|c|}
\hline \multirow{3}{*}{$\begin{array}{l}\text { Madde } \\
\text { Kullandığını belirten }\end{array}$} & \multicolumn{6}{|c|}{ ÖĞRENCİNİN MADDE KULLANMASI } & \multirow{3}{*}{$\begin{array}{l}\text { Toplam } \\
\text { f }(\%)\end{array}$} & \multirow{3}{*}{$\mathbf{p}$} \\
\hline & \multicolumn{2}{|l|}{ Evet } & \multicolumn{2}{|c|}{ Hayır } & \multicolumn{2}{|c|}{ Toplam } & & \\
\hline & $\mathbf{f}$ & $(\%)$ & $\mathbf{f}$ & $(\%)$ & f & $(\%)$ & & \\
\hline & 820 & 95,6 & 38 & 4,4 & 858 & 30,5 & 2814 & \\
\hline & 4 & 0,2 & 1952 & 99,8 & 1956 & 69,5 & $(29,3)$ & \\
\hline $\begin{array}{l}\text { Madde'yi } \\
\text { İşaretleyenlerin } \\
\text { Toplamı }\end{array}$ & 824 & 29,2 & 1990 & 70,7 & 2814 & 100 & $\begin{array}{l}2814 \\
(29,2)\end{array}$ & $\mathbf{0 , 0 0 0}$ \\
\hline
\end{tabular}

Lise öğrencileri, yaşamlarında en az bir kere narkotik madde kullanım oranlarına göre sınıflandırıldığında: Sigara \%29,3 (824 kişi), Alkol \%7,6 (214 kişi), esrar \%3,6 (100 kişi), Year 4/ 2020, Volume-4, Issue-3 | wwW.ispecjournal.org 
ekstazi \%1,5 (43 kişi), tiner-bali \%2,9 (82 kişi), akineton \%0,9 (26 kişi), kokain \%1,5 (42 kişi), eroin \%1,3 (36 kişi), amfetamin \%0,9 (25 kişi), captagon \%0,9 (25 kişi), yeşil reçete \%1,1 (32 kişi), diğer maddeler \%0,7 (20 kişi) kullandıkları bulunmuştur (Tablo 7).

Tablo 7: Yaşam boyu tüm lise öğrencilerinde en az bir kere madde kullanımına göre madde kullanım oran ve dağılımları

\section{ÖĞRENCINIIN MADDE KULLANMASI}

\begin{tabular}{|c|c|c|c|c|c|c|c|c|c|}
\hline \multicolumn{2}{|c|}{ Kullanılan Maddeler } & \multicolumn{2}{|l|}{ Evet } & \multicolumn{2}{|l|}{ Hayır } & \multicolumn{2}{|c|}{ Toplam } & \multirow{2}{*}{$\begin{array}{l}\text { Toplam } \\
\text { f }(\%)\end{array}$} & \multirow{2}{*}{$\mathbf{p}$} \\
\hline & & $\mathbf{f}$ & $(\%)$ & $\mathbf{f}$ & $(\%)$ & f & $(\%)$ & & \\
\hline \multirow{2}{*}{ Sigara } & Evet & 820 & 95,6 & 38 & 4,4 & 858 & 29,1 & \multirow{2}{*}{$\begin{array}{l}2814 \\
(29,3)\end{array}$} & \multirow[b]{2}{*}{0,000} \\
\hline & Hayır & 4 & 0,2 & 1952 & 99,8 & 1956 & 0,1 & & \\
\hline \multirow{2}{*}{ Alkol } & Evet & 213 & 24,8 & 645 & 75,1 & 858 & 7,6 & \multirow{2}{*}{$\begin{array}{r}2812 \\
(7,6)\end{array}$} & \multirow[b]{2}{*}{0,000} \\
\hline & Hayır & 1 & 0,1 & 1955 & 99,9 & 858 & 0,0 & & \\
\hline \multirow{2}{*}{ Esrar } & Evet & 100 & 11,7 & 758 & 88,3 & 858 & 3,6 & \multirow{2}{*}{$\begin{array}{l}2814 \\
(3,6)\end{array}$} & \multirow[b]{2}{*}{$\mathbf{0 , 0 0 0}$} \\
\hline & Hayır & 0 & 0,0 & 1956 & 100,0 & 1956 & 0,0 & & \\
\hline \multirow{2}{*}{ Ekstazi } & Evet & 43 & 5,0 & 815 & 95,0 & 858 & 1,5 & \multirow{2}{*}{$\begin{array}{l}\mathbf{2 8 1 4} \\
1,5)\end{array}$} & \multirow[b]{2}{*}{$\mathbf{0 , 0 0 0}$} \\
\hline & Hayır & 0 & 0,0 & 1956 & 100,0 & 1956 & 0,0 & & \\
\hline \multirow{2}{*}{ Tiner -bali } & Evet & 82 & 9,6 & 776 & 90,4 & 858 & 2,9 & \multirow{2}{*}{$\begin{array}{l}\mathbf{2 8 1 4} \\
(2,9)\end{array}$} & \multirow[b]{2}{*}{$\mathbf{0 , 0 0 0}$} \\
\hline & Hayır & 0 & 0,0 & 1956 & 100,0 & 1956 & 0,0 & & \\
\hline \multirow{2}{*}{ Akineton } & Evet & 26 & 3,0 & 832 & 97,0 & 858 & 0,9 & \multirow{2}{*}{$2814(0,9)$} & \multirow{2}{*}{0,000} \\
\hline & Hayır & 0 & 0,0 & 1956 & 100,0 & 1956 & 0,0 & & \\
\hline \multirow{2}{*}{ Kokain } & Evet & 42 & 4,9 & 816 & 95,1 & 858 & 1,5 & \multirow{2}{*}{$\begin{array}{l}\mathbf{2 8 1 4} \\
(1,5)\end{array}$} & \multirow[b]{2}{*}{0,000} \\
\hline & Hayır & 0 & 0,0 & 1956 & 100,0 & 1956 & 0,0 & & \\
\hline \multirow{2}{*}{ Eroin } & Evet & 36 & 4,2 & 822 & 95,8 & 858 & 1,3 & \multirow{2}{*}{$\begin{array}{l}\mathbf{2 8 1 4} \\
(1,3)\end{array}$} & \multirow[b]{2}{*}{$\mathbf{0 , 0 0 0}$} \\
\hline & Hayır & 0 & 0,0 & 1956 & 100,0 & 1956 & 0,0 & & \\
\hline \multirow{2}{*}{ Amfetamin } & Evet & 25 & 2,9 & 833 & 97,1 & 858 & & 2814 & \\
\hline & Hayır & 0 & 0,0 & 1956 & 100,0 & 1956 & 0,0 & $(0,9)$ & 0,000 \\
\hline Contoron & Evet & 25 & 2,9 & 833 & 97,1 & 858 & 0,9 & $(00)$ & \\
\hline apugant & Hayır & 0 & 0,0 & 1956 & 100,0 & 1956 & 0,0 & $201+(0,7)$ & 0,000 \\
\hline Yecil Pecoto & Evet & 32 & 3,7 & 826 & 96,3 & 858 & 1,1 & 2814 & \\
\hline 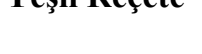 & Hayır & 0 & 0,0 & 1956 & 100,0 & 1956 & 0,0 & $(1,1)$ & 0,000 \\
\hline & Evet & 20 & 2,3 & 838 & 97,7 & 858 & 0,7 & 2814 & \\
\hline Diger t & Hayır & 0 & 0,0 & 1956 & 100,0 & 1956 & 0,0 & $(0,7)$ & 0,000 \\
\hline
\end{tabular}


Lise Türleri Öğrencilerinden hayatları boyunca en az bir kere madde kullanımını işaretleyenler toplam 2814 kişi olup narkotik madde kullandığını belirtenler \%30,5 (858 kişi), kullanmadığını belirtenler \%69,5 (1956 kişi) olarak bulunmuştur. Totaldeki Okul Türleri öğrencileri yaşamları boyunca en az bir kere madde kullanım oranlarına göre lise türlerine dağılımda: Fen Lisesi \%0,7 (19 kişi), Meslek Lisesi \%14,1 (397 kişi) Anadolu Lisesi \%15,7 (442 kişi) olarak belirlenmiştir (Tablo 8).

Tablo 8: Lise öğrencilerinde okul türlerine göre madde kullanım oranları

\begin{tabular}{|c|c|c|c|c|c|c|c|c|c|}
\hline \multirow{3}{*}{$\begin{array}{l}\text { OKUL } \\
\text { TÜRLERİ }\end{array}$} & \multicolumn{6}{|c|}{ ÖĞRENCİNİN MADDE KULLANMASI } & \multirow{3}{*}{$\begin{array}{l}\text { Total } \\
\text { f }(\%)\end{array}$} & & \multirow{3}{*}{$\mathbf{p}$} \\
\hline & \multicolumn{2}{|c|}{ EVET } & \multicolumn{2}{|c|}{ HAYIR } & \multicolumn{2}{|c|}{ TOPLAM } & & & \\
\hline & f & $\%$ & f & $\%$ & $\mathbf{f}$ & $\%$ & & & \\
\hline Fen Lisesi & 19 & 25,0 & 57 & 75,0 & 76 & 100,0 & 2814 & 0,7 & \\
\hline $\begin{array}{l}\text { Anadolu } \\
\text { Liseleri }\end{array}$ & 442 & 31,0 & 982 & 69,0 & 1424 & 100,0 & 2814 & 15,7 & \\
\hline Meslek Liseleri & 397 & 30,2 & 917 & 69,8 & 1314 & 100,0 & 2814 & 14,1 & $\mathbf{0 , 5 1 4}$ \\
\hline Toplam & 858 & 30,5 & 1956 & 69,5 & 2814 & 100,0 & 2814 & 30,5 & \\
\hline
\end{tabular}

Okul Türlerine göre, lise öğrencilerinde yaşamları boyunca en az bir kere madde kullanım oranlarına göre dağılımı:

a)Fen Lisesi: Sigara \%22,4 (17 kişi), Alkol \%7,9 (6 kişi), esrar kullanımı \%3,8 (54 kişi), ekstazi \%1,3 (1 kişi), tiner \%1,3 (1 kişi), akineton \%1,2 (17 kişi), kokain \%1,3 (1 kişi), eroin \%1,3 (1 kişi), amfetamin, captagon, yeşil reçete ve diğer'i \%0,0 (0 kişi);

b)Anadolu Lisesi: Sigara \%29,5 (420 kişi), Alkol \%7,8 (111 kişi), esrar kullanımı \%1,3 (1 kişi), ekstazi \%1,8 (25 kişi), tiner \%2,8 (40 kişi), akineton \%1,2 (17 kişi), kokain \%1,9 (27 kişi), eroin \%1,5 (21 kişi), amfetamin 1,1 (16 kişi), captagon \%0,8 (10 kişi), yeşil reçete \%1,5 (21 kişi), diğer \%0,6 (9 kişi);

c)Meslek Lisesi: Sigara \%29 (387 kişi), Alkol \%7,4 (97 kişi), esrar kullanımı \%3,4 (45 kişi), ekstazi \%1,3 (17 kişi), tiner \%3,1 (41 kişi), akineton \%0,7 (9 kişi), kokain \%1,1 (14 kişi), eroin \%1,1 (14 kişi), amfetamin \%0,7 (9 kişi), captagon \%0,0 (0 kişi), yeşil reçete \%0,8 (11 kişi), diğer \%0,8 (11 kişi) olarak bulunmuştur(Tablo 9).

Veriler incelendiğinde yaşam boyu en az bir kere madde kullanım oranı; Anadolu Lisesinde en yüksek, Fen Lisesinde en az olduğu; Meslek Liselerinde ise, hayat boyu en az bir kere madde kullanım oranları Fen Lisesinden yüksek, Anadolu Lisesinden de az olmasına karşılık, Lise türleri arasındaki oranlarda önemli bir anlamlılık bulunmamıştır (Tablo 8, 9). 
Tablo 9: Lise öğrencilerinde madde kullanım oranlarının okul türlerine göre dağılımı

\begin{tabular}{|c|c|c|c|c|c|c|c|}
\hline \multirow{3}{*}{$\begin{array}{l}\text { KULLANILAN } \\
\text { MADDELER }\end{array}$} & \multicolumn{7}{|c|}{ OKUL TÜRLERİ } \\
\hline & \multicolumn{2}{|c|}{ Fen Lisesi } & \multicolumn{2}{|c|}{ Anadolu Liseleri f } & \multicolumn{2}{|c|}{ Meslek Liseleri } & \multirow{2}{*}{$\mathbf{p}$} \\
\hline & $f(\%)$ & Total & $f(\%)$ & Total & $f(\%)$ & Total & \\
\hline Sigara & $17(22,4)$ & 76 & $420(29,5)$ & 1424 & $387(29)$, & 1314 & 0,406 \\
\hline Alkol & $6(7,9)$ & 76 & $111(7,8)$ & 1424 & $97(7,4)$ & 1314 & 0,916 \\
\hline Esrar & $1(1,3)$ & 76 & $54(3,8)$ & 1424 & $45(3,4)$ & 1314 & 0,494 \\
\hline Ekstazi & $1(1,3)$ & 76 & $25(1,8)$ & 1424 & $17(1,3)$ & 1314 & 0,609 \\
\hline Tiner -Bali & $1(1,3)$ & 76 & $40(2,8)$ & 1424 & $41(3,1)$ & 1314 & 0,625 \\
\hline Akineton & $0(0,0)$ & 76 & $17(1,2)$ & 1424 & $9(0,7)$ & 1314 & 0,264 \\
\hline Kokain & $1(1,3)$ & 76 & $27(1,9)$ & 1424 & $14(1,1)$ & 1314 & 0,200 \\
\hline Eroin & $1(1,3)$ & 76 & $21(1,5)$ & 1424 & $14(1,1)$ & 1314 & 0,635 \\
\hline Amfetamin & $0(0,0)$ & 76 & $16(1,1)$ & 1424 & $9(0,7)$ & 1314 & 0,334 \\
\hline Captagon & $0(0,0)$ & 76 & $15(1,1)$ & 1424 & $10(0,8 \%)$ & 1314 & 0,506 \\
\hline Yeşil Reçete & $0(0,0)$ & 76 & $21(1,5)$ & 1424 & $11(0,8)$ & 1314 & 0,185 \\
\hline Diğer & $0(0,0)$ & 76 & $9(0,6)$ & 1424 & $11(0,8)$ & 1314 & 0,617 \\
\hline
\end{tabular}

Lise öğrencilerinin narkotik madde kullanım oranları sınıflara göre değerlendirildiğinde, narkotik madde kullanım oranları sınıflar arasında farklılık olduğu görüldü; sınıflar arası farklar ikili karşılaştırmalarla değerlendirildiğinde ise, narkotik madde kullanım oranları sınıflar arası oranlandığında 10.sınıflara oranla 12.sınıflarda anlamlı olarak daha yüksek olduğu görülmektedir(Tablo 10, 11, 12, 13).

Tablo10: Lise öğrencilerinde 10. ve 12. sınıflara göre madde kullanım oranları

\begin{tabular}{|c|c|c|c|c|c|c|c|c|c|}
\hline \multirow{3}{*}{ SINIFLAR } & \multicolumn{6}{|c|}{ ÖĞRENCİNİN MADDE KULLANMASI } & \multirow{3}{*}{$\begin{array}{l}\text { Total } \\
\text { f }(\%)\end{array}$} & & \multirow{3}{*}{$\mathbf{p}$} \\
\hline & \multicolumn{2}{|c|}{ EVET } & \multicolumn{2}{|c|}{ HAYIR } & \multicolumn{2}{|c|}{ TOPLAM } & & & \\
\hline & $\mathbf{f}$ & $\%$ & $\mathbf{f}$ & $\%$ & $\mathbf{f}$ & $\%$ & & & \\
\hline 10.sınıf & 382 & 26,6 & 1052 & 73,4 & 1434 & 100,0 & 2795 & 13,7 & \\
\hline 12.sinıf & 468 & 34,4 & 893 & 65,6 & 1361 & 100,0 & 2795 & 16,7 & \\
\hline Toplam & 850 & $30,4 \%$ & 1945 & 69,6 & 2795 & 100,0 & 2795 & 30,4 & \\
\hline
\end{tabular}


Tablo 11: Lise öğrencilerinde madde kullanım oranlarının sınıflara göre dağılımı

\begin{tabular}{|c|c|c|c|c|c|c|c|c|c|}
\hline \multirow[b]{2}{*}{$\begin{array}{l}\text { KULLANILAN } \\
\text { MADDELER }\end{array}$} & \multicolumn{3}{|l|}{ 10.sinıf } & \multicolumn{3}{|c|}{ 12.sinıf } & \multicolumn{2}{|c|}{$\begin{array}{l}\text { TOPLAM } \\
\text { f }(\%)\end{array}$} & \multirow[b]{2}{*}{$\mathbf{p}$} \\
\hline & $\begin{array}{l}\text { Evet } \\
\text { f }(\%)\end{array}$ & $\begin{array}{l}\text { Hayır } \\
\text { f }(\%)\end{array}$ & $\begin{array}{l}\text { Toplam } \\
\text { f }(\%)\end{array}$ & $\begin{array}{l}\text { Evet } \\
\text { f }(\%)\end{array}$ & $\begin{array}{l}\text { Hayır } \\
\text { f }(\%)\end{array}$ & $\begin{array}{l}\text { Toplam } \\
\text { f }(\%)\end{array}$ & $\mathbf{f}(\%)$ & & \\
\hline Sigara & $\begin{array}{l}367 \\
(25,6)\end{array}$ & $\begin{array}{l}1067 \\
(74,4)\end{array}$ & $\begin{array}{l}1434 \\
(100)\end{array}$ & $\begin{array}{l}449 \\
(33,0)\end{array}$ & $\begin{array}{l}912 \\
(67,0)\end{array}$ & $\begin{array}{l}1361 \\
(100)\end{array}$ & $\begin{array}{l}\mathbf{8 1 6} \\
(29,2)\end{array}$ & $\begin{array}{l}2795 \\
(100)\end{array}$ & $\mathbf{0 , 0 0 0}$ \\
\hline Alkol & $\begin{array}{l}75 \\
(5,2)\end{array}$ & $\begin{array}{l}1359 \\
(94,8)\end{array}$ & $\begin{array}{l}1434 \\
(100)\end{array}$ & $\begin{array}{l}137 \\
(10,1)\end{array}$ & $\begin{array}{l}1222 \\
(89,9)\end{array}$ & $\begin{array}{l}1359 \\
(100)\end{array}$ & $\begin{array}{l}212 \\
(7,6)\end{array}$ & $\begin{array}{l}\mathbf{2 7 9 5} \\
(100)\end{array}$ & $\mathbf{0 , 0 0 0}$ \\
\hline Esrar & $\begin{array}{l}42 \\
(2,9)\end{array}$ & $\begin{array}{l}1392 \\
(97,1)\end{array}$ & $\begin{array}{l}1434 \\
(100)\end{array}$ & $\begin{array}{l}57 \\
(4,2)\end{array}$ & $\begin{array}{l}1304 \\
(95,8)\end{array}$ & $\begin{array}{l}1361 \\
(100)\end{array}$ & $\begin{array}{l}99 \\
(3,5)\end{array}$ & $\begin{array}{l}2795 \\
(100)\end{array}$ & $\mathbf{0 , 0 7 2}$ \\
\hline Ekstazi & $\begin{array}{l}20 \\
(1,4)\end{array}$ & $\begin{array}{l}1414 \\
(98,6)\end{array}$ & $\begin{array}{l}1434 \\
(100)\end{array}$ & $\begin{array}{l}22 \\
(1,6)\end{array}$ & $\begin{array}{l}1339 \\
(98,4)\end{array}$ & $\begin{array}{l}1361 \\
(100)\end{array}$ & $\begin{array}{l}42 \\
(1,5)\end{array}$ & $\begin{array}{l}2795 \\
(100)\end{array}$ & $\mathbf{0 , 6 3 0}$ \\
\hline Tiner -Bali & $\begin{array}{l}43 \\
(3,0)\end{array}$ & $\begin{array}{l}1391 \\
(97,0)\end{array}$ & $\begin{array}{l}1434 \\
(100)\end{array}$ & $\begin{array}{l}39 \\
(2,9)\end{array}$ & $\begin{array}{l}1322 \\
(97,1)\end{array}$ & $\begin{array}{l}1361 \\
(100)\end{array}$ & $\begin{array}{l}82 \\
(2,9)\end{array}$ & $\begin{array}{l}2795 \\
(100)\end{array}$ & $\mathbf{0 , 8 3 5}$ \\
\hline Akineton & $\begin{array}{l}14 \\
(1,0)\end{array}$ & $\begin{array}{l}1420 \\
(99,0)\end{array}$ & $\begin{array}{l}1434 \\
(100)\end{array}$ & $\begin{array}{l}12 \\
(0,9)\end{array}$ & $\begin{array}{l}1349 \\
(99,1)\end{array}$ & $\begin{array}{l}1361 \\
(100)\end{array}$ & $\begin{array}{l}26 \\
(0,9)\end{array}$ & $\begin{array}{l}2795 \\
(100)\end{array}$ & 0,795 \\
\hline Kokain & $\begin{array}{l}22 \\
(1,5)\end{array}$ & $\begin{array}{l}1412 \\
(98,5)\end{array}$ & $\begin{array}{l}1434 \\
(100)\end{array}$ & $\begin{array}{l}19 \\
(1,4)\end{array}$ & $\begin{array}{l}1342 \\
(98,6)\end{array}$ & $\begin{array}{l}1361 \\
(100)\end{array}$ & $\begin{array}{l}\mathbf{4 1} \\
(1,5)\end{array}$ & $\begin{array}{l}2795 \\
(100)\end{array}$ & 0,761 \\
\hline Eroin & $\begin{array}{l}21 \\
(1,5)\end{array}$ & $\begin{array}{l}1413 \\
(98,5)\end{array}$ & $\begin{array}{l}1434 \\
(100)\end{array}$ & $\begin{array}{l}14 \\
(1,0)\end{array}$ & $\begin{array}{l}1347 \\
(99,0)\end{array}$ & $\begin{array}{l}1361 \\
(100)\end{array}$ & $\begin{array}{l}\mathbf{3 5} \\
(1,3)\end{array}$ & $\begin{array}{l}2795 \\
(100)\end{array}$ & $\mathbf{0 , 3 0 0}$ \\
\hline Amfetamin & $\begin{array}{l}14 \\
(1,0)\end{array}$ & $\begin{array}{l}1420 \\
(99,0)\end{array}$ & $\begin{array}{l}1434 \\
(100)\end{array}$ & $\begin{array}{l}10 \\
(0,7)\end{array}$ & $\begin{array}{l}1351 \\
(99,3)\end{array}$ & $\begin{array}{l}1361 \\
(100)\end{array}$ & $\begin{array}{l}\mathbf{2 4} \\
(0,9)\end{array}$ & $\begin{array}{l}2795 \\
(100)\end{array}$ & 0,489 \\
\hline Captagon & $\begin{array}{l}14 \\
(1,0)\end{array}$ & $\begin{array}{l}1420 \\
(99,0)\end{array}$ & $\begin{array}{l}1434 \\
(100)\end{array}$ & $\begin{array}{l}11 \\
(0,8)\end{array}$ & $\begin{array}{l}1350 \\
(99,2)\end{array}$ & $\begin{array}{l}1361 \\
(100)\end{array}$ & $\begin{array}{l}\mathbf{2 5} \\
(0,9)\end{array}$ & $\begin{array}{l}2795 \\
(100)\end{array}$ & 0,637 \\
\hline Yeşil Reçete & $\begin{array}{l}18 \\
(1,3)\end{array}$ & $\begin{array}{l}1416 \\
(98,7)\end{array}$ & $\begin{array}{l}1434 \\
(100)\end{array}$ & $\begin{array}{l}14 \\
(1,0)\end{array}$ & $\begin{array}{l}1347 \\
(99,0)\end{array}$ & $\begin{array}{l}1361 \\
(100)\end{array}$ & $\begin{array}{l}\mathbf{3 2} \\
(1,1)\end{array}$ & $\begin{array}{l}2795 \\
(100)\end{array}$ & $\mathbf{0 , 5 7 4}$ \\
\hline Diğer & $\begin{array}{l}10 \\
(0,7)\end{array}$ & $\begin{array}{l}1424 \\
(99,3)\end{array}$ & $\begin{array}{l}1434 \\
(100)\end{array}$ & $\begin{array}{l}10 \\
(0,7)\end{array}$ & $\begin{array}{l}1351 \\
(99,3)\end{array}$ & $\begin{array}{l}1361 \\
(100)\end{array}$ & $\begin{array}{l}\mathbf{2 0} \\
(0,7)\end{array}$ & $\begin{array}{l}2795 \\
(100)\end{array}$ & 0,907 \\
\hline
\end{tabular}

Tablo 12: Lise 10.sınıf öğrencilerinde madde kullanım oranlarının dağılımı

\begin{tabular}{|c|c|c|c|c|c|}
\hline \multirow{4}{*}{$\begin{array}{l}\text { KULLANILAN } \\
\text { MADDELER }\end{array}$} & 10.SINIF & ÖĞRENCİLE & MADDE & \multirow{4}{*}{$\begin{array}{l}\text { TOPLAM } \\
\text { f }(\%)\end{array}$} & \\
\hline & \multicolumn{3}{|c|}{ KULLANIMI } & & \\
\hline & Evet & Hayır & Toplam & & \\
\hline & $\mathbf{f}(\%)$ & $\mathbf{f}(\%)$ & $\mathbf{f}(\%)$ & & \\
\hline Sigara & $367(25,6)$ & $1067(74,4)$ & $1434(100)$ & $367(13,1)$ & 2795(100) \\
\hline Alkol & $75(5,2)$ & $1359(94,8)$ & 1434(100) & $75(2,7)$ & $2793(100)$ \\
\hline Esrar & $42(2,9)$ & $1392(97,1)$ & $1434(100)$ & $42(1,5)$ & 2795(100) \\
\hline
\end{tabular}

Year 4/ 2020, Volume-4, Issue-3 | www.ispecjournal.org 
ISSN 2717-7262 ISPEC Journal of Social Sciences \& Humanities

\begin{tabular}{llllll}
\hline Ekstazi & $20(1,4)$ & $1414(98,6)$ & $1434(100)$ & $\mathbf{2 0}(0,7)$ & $\mathbf{2 7 9 5}(100)$ \\
\hline Tiner -Bali & $43(3,0)$ & $1391(97,0)$ & $1434(100)$ & $\mathbf{4 3}(1,5)$ & $\mathbf{2 7 9 5}(100)$ \\
\hline Akineton & $14(1,0)$ & $1420(99,0)$ & $1434(100)$ & $\mathbf{1 4}(0,5)$ & $\mathbf{2 7 9 5}(100)$ \\
\hline Kokain & $22(1,5)$ & $1412(98,5)$ & $1434(100)$ & $\mathbf{2 2}(0,8)$ & $\mathbf{2 7 9 5}(100)$ \\
\hline Eroin & $21(1,5)$ & $1413(98,5)$ & $1434(100)$ & $\mathbf{2 1}(0,8)$ & $\mathbf{2 7 9 5}(100)$ \\
\hline Amfetamin & $14(1,0)$ & $1420(99,0)$ & $1434(100)$ & $\mathbf{1 4}(0,5)$ & $\mathbf{2 7 9 5}(100)$ \\
\hline Captagon & $14(1,0)$ & $1420(99,0)$ & $1434(100)$ & $\mathbf{1 4}(0,5)$ & $\mathbf{2 7 9 5}(100)$ \\
\hline Yeşil Reçete & $18(1,3)$ & $1416(98,7)$ & $1434(100)$ & $\mathbf{1 8}(0,6)$ & $\mathbf{2 7 9 5}(100)$ \\
\hline Diğer & $10(0,7)$ & $1424(99,3)$ & $1434(100)$ & $\mathbf{1 0}(0,4)$ & $\mathbf{2 7 9 5}(100)$ \\
\hline
\end{tabular}

Tablo 13: Lise 12.sınıf öğrencilerinde madde kullanım oranlarının dağılımı

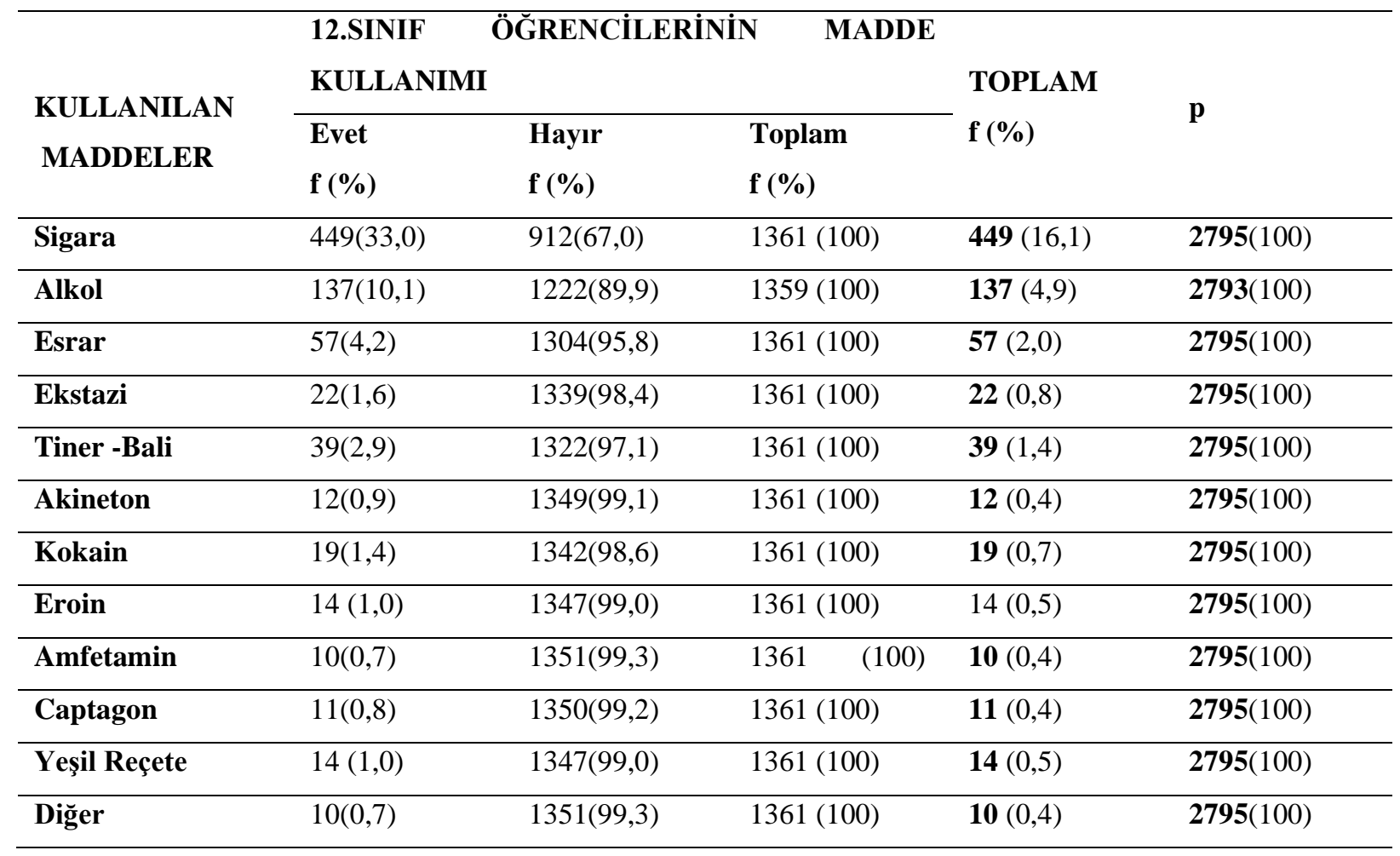

Lise öğrencilerinin narkotik madde kullanım oran dağılımları sınıflara göre değerlendirildiğinde; siğara, alkol, esrar ve ekestazi kullanımı 12.sınıflarda 10.sınıflara göre anlamlı olarak daha yüksek olduğu; ama diğer tüm narkotik madde kullanımlarında 10.sınıflarda 12.sınıflara göre anlamlı olarak daha fazla olduğu görülmektedir (Tablo 10, 11, $12,13)$. 
Tablo 14: Öğrencilerin kullandıkları maddeleri teminde zorluk çekip çekmediğini oranları

\begin{tabular}{|c|c|c|c|c|c|c|c|c|}
\hline \multirow{3}{*}{$\begin{array}{l}\text { Maddeyi temin } \\
\text { etme şekli }\end{array}$} & \multicolumn{6}{|c|}{ Öğrencinin madde kullanması durumu } & \multirow{3}{*}{$\begin{array}{l}\text { Toplam } \\
\text { f }(\%)\end{array}$} & \multirow[t]{3}{*}{$\mathbf{p}$} \\
\hline & \multicolumn{2}{|c|}{ Evet } & \multicolumn{2}{|c|}{ Hayır } & \multicolumn{2}{|c|}{ Toplam } & & \\
\hline & f & $(\%)$ & f & $(\%)$ & f & $f(\%)$ & & \\
\hline $\begin{array}{l}\text { Hiç zorluk } \\
\text { yaşamiyorum }\end{array}$ & 249 & 94,7 & 14 & 5,3 & 263 & $\mathbf{3 6 5}(68,2)$ & $2814(8,9)$ & $\mathbf{0 , 6 4 1}$ \\
\hline $\begin{array}{ll}\text { Biraz } & \text { zorluk } \\
\text { yaşıyorum } & \end{array}$ & 75 & 94,9 & 4 & 5,1 & 79 & $365(20,5)$ & $2814(2,7)$ & $\mathbf{0 , 6 4 1}$ \\
\hline $\begin{array}{l}\text { Oldukça zor-luk } \\
\text { yaşıyorum }\end{array}$ & 6 & 100,0 & 0 & 0,0 & 6 & $365(1,6)$ & 2814(0,02) & $\mathbf{0 , 6 4 1}$ \\
\hline $\begin{array}{ll}\text { Çok } & \text { zorluk } \\
\text { yaşıyorum } & \end{array}$ & 15 & 88,2 & 2 & 11,8 & 17 & $365(4,1)$ & 2814(0,05) & $\mathbf{0 , 6 4 1}$ \\
\hline Toplam & 345 & 94,5 & 20 & 5,5 & 365 & $365(94,5)$ & $\mathbf{2 8 1 4}(12,3)$ & $\overline{0,641}$ \\
\hline
\end{tabular}

Çalışmaya katılıp da sigara ve alkol dışında herhangi bir madde kullanımı olan öğrencilerin bunu nasıl temin ettiğini belirten 365 öğrenciden \%68,2 (249 kişi) öğrenci maddeye ulaşmakta hiç zorluk çekmediğini belirtmiştir (Tablo 15). Ankete katılıp da hayat boyu en az bir kere madde kullanımı olan öğrencilerin, kullandıkları maddeyi nasıl temin ettikleri ile ilgili olarak; \%52,3'ü en fazla arkadaşlarından; öğrencilerin \%19,6'1 ikinci sıklıkta madde sat1c1larından, \%11,2’i ise sevgiliden temin ettiklerini bildirmektediler (Şekil 1, Tablo 14, 15)

\section{Öğrencilerin Madde Temin Yerleri}

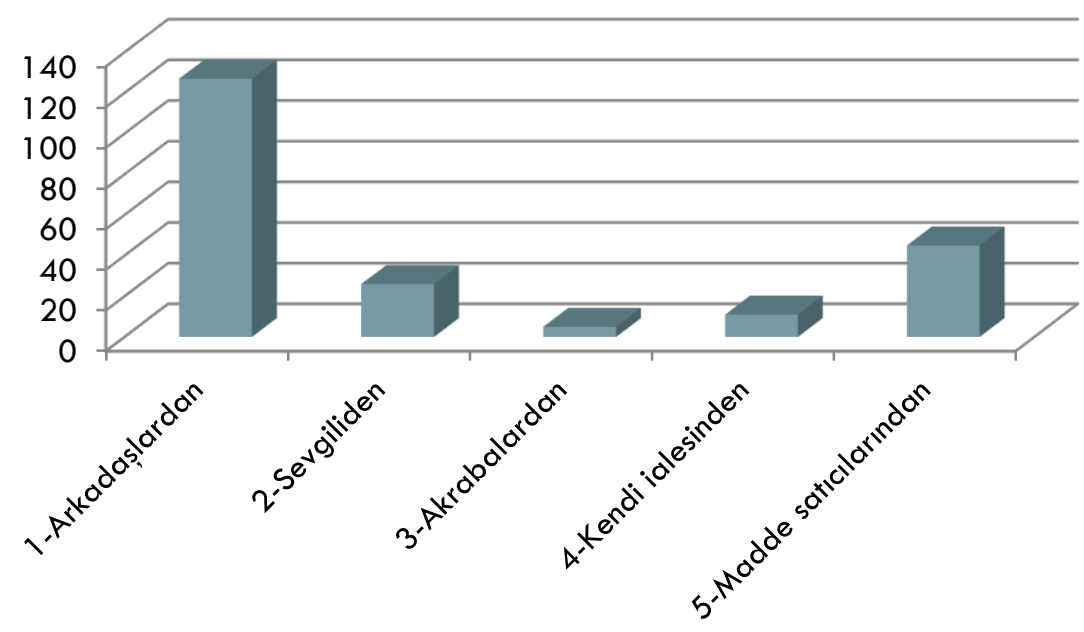

Şekil 1: Sigara ve Alkol dışında herhangi bir madde

kullanımı olan öğrencilerin bunu temin ettiği kişilerin oranları 
Tablo 15: Sigara ve Alkol dışında herhangi bir madde kullanımı olan öğrencilerin bunu temin ettiği kişilerin oranları

\begin{tabular}{|c|c|c|c|c|c|c|c|c|}
\hline \multirow{3}{*}{$\begin{array}{l}\text { Madde } \\
\text { yerleri }\end{array}$} & \multicolumn{6}{|c|}{ Öğrencinin madde kullanması durumu } & \multirow{3}{*}{$\begin{array}{l}\text { Toplam } \\
\text { f (\%) }\end{array}$} & \multirow[t]{3}{*}{$\mathbf{p}$} \\
\hline & \multicolumn{2}{|l|}{ Evet } & \multicolumn{2}{|l|}{ Hayır } & \multicolumn{2}{|c|}{ Toplam } & & \\
\hline & $\mathbf{f}$ & $(\%)$ & $\mathbf{f}$ & $(\%)$ & $\mathbf{f}$ & $\mathbf{f}(\%)$ & & \\
\hline Arkadaşlardan & 112 & 88,2 & 15 & 11,8 & 127 & $214(52.3)$ & $2814(4,0)$ & 0,795 \\
\hline Sevgiliden & 24 & 92,3 & 2 & 7,7 & 26 & $214(11.2)$ & $2814(0.9)$ & 0,795 \\
\hline Akrabalardan & 4 & 80,0 & 1 & 20,0 & 5 & $214(1.9)$ & $2814(0.14)$ & 0,795 \\
\hline Kendi ailesinden & 10 & 90,9 & 1 & 9,1 & 11 & $214(4.7)$ & $2814(0.36)$ & 0,795 \\
\hline $\begin{array}{l}\text { Madde } \\
\text { satıcılarından }\end{array}$ & 42 & 93,3 & 3 & 6,7 & 45 & $214(19,6)$ & $2814(1.5)$ & 0,795 \\
\hline Toplam & 192 & 89,7 & 22 & 10,3 & 214 & $214(89,7)$ & $2814(6.8)$ & \\
\hline
\end{tabular}

Öğrencilerin narkotik maddeyi temin ettiği yerlere kolay ulabilirliğinin madde kullanımının yükseliş oranında önemli bir anlamlılık görülmektedir.

\section{Tartışma}

$\mathrm{Bu}$ araştırmada her üç grup öğrencilerde kullanımı en fazla olan narkotik maddeler sigara, alkol ve esrar olarak bulunmuştur. Sigara, alkol, esrar ve ekstazi kullanım oranları lise 10.sınıf öğrencilerinde 12.sınıf öğrencilerinden anlamlı olarak daha yüksek olduğu belirlenmiştir. Ancak sigara, alkol, esrar ve ekstazi kullanım oranları dışındaki tüm maddelerde ise lise 12.sınıf öğrencileri 10.sınıf öğrencilerinden anlamlı olarak daha yüksek bulunmuştur.

-Bu çalışmada her üç lise türü öğrencilerde dahi madde kullanımı en çok olan maddeler sigara, alkol ve esrar olarak bulunmuştur. Verilere bakıldığında yaşam boyu en az bir kere madde kullanım oranı; Anadolu Lisesinde en yüksek, Fen Lisesinde en az olduğu; Meslek Liselerinde ise, hayat boyu en az bir kere madde kullanım oranları Fen Lisesinden yüksek Anadolu Lisesinden de az olmasına karşılık okul türleri arasındaki oranlarda önemli bir anlamlılık bulunmamıştır.

Ve yine bu araştırmada ankete katılıp da yaşam boyu en az bir kere madde kullanımı olan lise öğrencilerinin kullandıkları narkotik maddeyi nasıl temin ettikleri ile ilgili olarak; \%68,2'si maddeye ulaşmakta hiç zorluk çekmediğini, \%52,3'ü maddesyi en çok arkadaşlarından; Year 4/ 2020, Volume-4, Issue-3 | WwW.ispecjournal.org 
öğrencilerin \%19,6'1 ise ikinci sıklıkta narkotik madde satıcılarından, \%11,2'i sevgiliden maddeyi temin ettiklerini bildirdileri tespit edilmiştir.

Türkiye'deki en büyük çaplı iki araştırma lise 1. ile 2.sınıflarda yürütülmüş olduğu görülmektedir (Yıldız, 2009, s. 36). Ögel ve ark.larının 1998'de SAMAY ile beraber yapmış oldukları bu çalışma lise ikinci sınıflar(10. sınıflar)da yürütülmüştür. Bunun Van İli'ni de içine almış olması bizim çalışmamız bakımından önem arz etmektedir. Araştırmada öğrencilerin yaşam boyu madde kullanım yaygınlıkları sırasıyla: Uçucu maddeler \%8.6, Esrar \%3.5, Sedatif Hipnotik maddeler \%3.2, Eroin \%1.6 olarak bulunmuştur. Öğrencilerde yaşam boyu esrar kullanımının en sık görüldüğü illerin: İzmir \%4, İstanbul ve Diyarbakır \%3.6, Muğla \%3.4, Antalya \%3.2, Adana \%3.1 olarak belirtilmektedir.

Öğrencilerde yaşam boyu esrar kullanımının en az görüldüğ̈̈ iller: Malatya \%0.5, Sivas ile Van \%1.9 olduğu görülmüştür.

Uçucu madde kullanımının en sık olduğu iller: Muğla \%12.8, Kocaeli \%12.6, Sivas \%12.4, Eskişehir \%11.8, Antalya \%11.2 ve İzmir \%11.1 olarak bulunmuştur (Yıldız, 2009, s. 3, 37 38; Ögel, 2005, s. 62).

$\mathrm{Bu}$ araştırmamızın verileri değerlendirildiğinde, öğrencilerde yaşam boyu en az bir defa madde kullanım yaygınlıkları sırasıyla şöyle bulunmuştur: En fazla kullanılan madde \%29,3 oranıly sigara ve \%7,6 oranıla alkol olup bunları sirasiyla: Kanuni olmayan esrar \%3,6, tiner-bali $\% 2,9$, ekstazi ve kokain $\% 1,5$, eroin $\% 1,3$, yeşil reçete $\% 1,1$, akineton ve emfatamin ile captagon \%0,9 maddeleri takip eder. Bütün ülkemizde olduğu gibi Van ilinde de Ögel ve ark.larının 1998'de SAMAY 'la birlikte yapmış oldukları araştırmada bulunan esrar kullanımı sıklığı bu çalışmamızda da artmış olmasına karşın; Van İlindeki öğrencilerin yaşam boyu en az bir kere tüm madde kullanımlarında1998 yılındaki ülkemizde yapılmış olan bu kapsamlı verileriyle kaşılaştırıldığında düşük bulunmuştur.

Avrupa Okul Anketi Projesi'nin (ESPAD) Alkol ve Diğer Uyuşturucular (narkotik maddeler) Kullanımına Yönelik 2007 tarihli çalışmasına 100.000'den fazla öğrenci katılmış, katılımcı devletlerdeki yaşları 15-16 arasında değișen öğrencilerin ortalama \%58'i en az bir defa sigara kullandığı, öğrencilerin en azından üçte biri yaşamları boyunca en az bir kez alkol kullandığını, erkeklerin \%23'ü ve kızların \%17'si yaşamları boyunca en az bir defa yasadışı uyuşturucu denediğini bildirmiştir (ESPAD, 2007, s. 10, 13).

$\mathrm{Bu}$ araştırmamızdaki alkol kullanım oranları ESPAD’ın bu çalışmasıyla benzerdir; fakat çalışmamızdaki sigara ve hukuki olmayan maddelerin kullanım oranları ESPAD’ın 
çalışmasından daha düşüktür. ESPAD araştırmasında yasal olmayan uyuşturucu denemiş olan öğrencilerin büyük çoğunluğu esrar kullanmıştır. Bizim araştırmasında da en çok kullanılan madde esrardır. ESPAD araştırmasında öğrencilerin \%19'u hayat boyu esrar kullanımı bildirilirken, \%7'si indekste yer alan diğer uyuşturuculardan bir ya da daha çoğunu denediği belirtilmiştir. Ekstazi, kokain ve amfetaminler çok az arayla (her biri \%3) birbirini takip etmekte olup, amfetamin, kokain ve eroin daha az olduğu rapor edilmiştir (\%1-2). (ESPAT, 2007, s. 13). Bizim verilerimizle ESPAD'ın 2007 yllı verileri karşılaştırıldığında; Avrupa ülkelerinde sigara, esrar, eroin, kokain, LSD ve ekstazi kullanım oranlarının çalışma verilerimizden oldukça yüksek olduğu, alkol kullanım oranlarının ise verilerimize benzer olduğu tespit edilmiştir.

Ögel ve ark.nın yapmış olduğu 7341 lise 2.sınıf (10.sınıf) öğrencilerinin dahil edildiği çalışmalarında: Öğrencilerin \%65,1'inin hayatları boyunca en az bir kez sigara kullandıklarını belirlemişler olmalarına karşılık bizim çalışmada bu oran \%29,3'dir. Bu araştırmada hayat boyu esrar \%3.6, uyarıcı madde $\% 8,6$ ve uçucu madde $\% 3,3$ oranlarında kullandıkları bulunmuştur. Bizim çalışmada nokta yaygınlığı olarak bu maddelerin kullanım oranları bu çalışmadan daha düşük bulunmuştur (Ögel, Tamar, Evren, Çakmak, 2000, s. 243-244). Ve yine Ülkemizin 9 büyük ilinde 11.991 10.sınıf öğrencisinde Ögel ve ark. tarafindan yapılan diğer bir araştırmada ise, hayat boyu ekstazi kullanımı \%2.5 bulunmuştur. Bizim araştırmamızla karşılaş̧ıııldığında ise, bu oran da daha yüksektir. $\mathrm{Bu}$ araştırmaların İstanbul'daki liselerde yapıldığı göz önüne alındığında, bu farklılıkların iller arasındaki sosyolojik yapı farklılıklarından kaynaklanmış olabileceği düşünmektedir (Ögel vd., 2004, s. 112-118).

İstanbul'da lise 10.sınıf öğrencilerinde 2004 yılında Gençlik Araştırmasında: Öğrencilerde hayat boyu en az bir kez madde kullanım yaygınlığı en yüksek olan \%51,2 oranla alkol olup bunu sırasiyla tütün $\% 37$, uçucu maddeler $\% 5,9$ ve esrar $\% 5,8$ oranlarılya takip etmektedirler (Ögel, Taner ve Eke, 2006, s. 18-23). Narkotik Madde Kullanım sıklığı bizim çalışmamızda daha düşük bulunmuştur. Yani bizim çalışmamızda lise 10.sınıftaki öğrencilerde en fazla kullanılan maddeler: sigara $\% 13,1$ ve alkol $\% 2,7^{\prime}$ dir. Bunları esrar $\% 1,5$, tiner-bali $\% 1,5$ ve eroin ile kokain $\% 0,8$ oranlarıla takip etmektedir.

İstanbul'da 2010 yılında 'Liseli Gencler Arasındaki Madde Kullanım Yaygınlı̆̆ ve Demokrafik Faktörlerin Etkileri’ Araştırmasında, İstanbul ilindeki 28 ilçede 154 orta öğretim okulunda bulunan 31.272 öğrenciye anket uygulanıp veriler toplanmıştır. Öğrenciler arasında 
yaşam boyu en az bir kez kullanım yaygınlığı en yüksek olan madde $\% 45.5$ oranıyla sigaradır. Sigarayı sırasıyla alkol \%32.5, esrar \%3.3, ucucu maddeler \%2.4 ve ekstazi \%1.6 oranlarıyla takip etmektedirler. Bu her iki araştırma bizim araştırmamızla karşılaştırıldığında, bu oranlar da daha yüksektir.

2010 yılındaki diğer bir çalışmada,yaşam boyu en az bir kez sigara kullanım oranında Okul Türlerinde ilk sırayı Meslek Liseleri (\%49.8), sonrasında ise sırasıyla Düz Liseler (\%42.3) ve Anadolu Liseleri (\%37.2) oluşturmaktadır. Yaşam boyu en az bir kez alkol kullanım oranında Okul Türlerinde ilk sırayı Anadolu Liseleri (\%39.7), sonrasında ise sırasıyla Düz Liseler (\%31.6) ve Meslek Liseleri (\%30.5) oluşturmaktadır. Yaşam boyu en az bir kez esrar kullanım oranında okul türlerinde ilk sırayı Meslek Liseleri (\%4.1), sonrasında ise sirasıyla Düz Liseler (\%3.1) ve Anadolu Liseleri (\%1.8) oluşturmaktadır.

Liselerin kendi aralarındaki anlamlılığına bakıldığı çalışmadaki anlamlılık değerleri incelendiğinde; yaşam boyu en az bir kez sigara ve esrar kullanım oranlarında Okul Türlerinin hepsinin kendileri aralarında anlamlı bir farklılı̆̆ının olduğu, yaşam boyu en az bir kez alkol kullanım oranında ise Okul Türlerinden sadece Anadolu Liselerinin diğer liselerle anlamlı bir farklılığının olduğu tesbit edilmiştir (Ünlü ve Evcin, 2010, s. 5).

Bizim araştırmamızdaki Lise Okul Türlerinde madde kullanım sıklığı öğrenciler arasında en çok kullanılan madde \%29,3'le sigaradır. Bunu alkol \%7,6, esrar \%3,6, tiner-bali \%2,9 ve ekstazi \%1,5 oranlarıyla takip etmektedir. Okul Türlerine göre öğrencilerden hayat boyunca en az bir kere madde kullanımını işaretleyenler toplam 2814 kişi olup bunlardan kullandığını belirten \%30,5 (858 kişi), kullanmadığını belirten \%69,5 (1956 kişi) olarak bulunmuştur. Özelde Lise Türleri arasında Genel Liseler (Genel-Anadolu-Fen) ile meslek (Endüstri-İmam Hatip-Güzel Sanatlar ve Spor) liseleri öğrencilerindeki yaşam boyu en az bir kere madde kullanım oran ve dağılımları: Fen Lisesi \%25, Meslek Liseleri 30,2\%, Anadolu Lisesi 31,0\%, olarak bulunmuştur. Totalde ise, lise öğrencileri yaşam boyu en az bir kere madde kullanım oranlarına göre sınıflandırıldığında: Fen Lisesi \%0,7 (19 kişi), Meslek Lisesi \%14,1 (397 kişi) Anadolu Lisesi 442 kişi $(\% 15,7)$ olarak belirlenmiştir. Verilerde hayat boyu en az bir kere madde kullanım oranı; Anadolu Lisesinde en yüksek, Fen Lisesinde en az olduğu; Meslek Lisesinde ise, hayat boyu en az bir kere madde kullanım oranları Fen Lisesinden de yüksek, Anadolu Lisesinden az olmasına karşılık okul türleri arasındaki oranlarda önemli bir anlamlılık bulunmamıştır. 
2011'de Edirne ili Liselerindeki 8402 lise öğrencisine uygulanan ankette; lise 12.sınıf öğrencilerinden elde edilen verilerde yaşam boyu en az bir kez kullanım yaygınlığı en yüksek olan madde \%35.7'le sigaradır. Bunu sırasıyla alkol \%28.6'la, esrar \%3'le, uçucu maddeler \%1,9'la izlemektedir. Bizim araştırmamızda, yaşam boyu en az bir kez kullanım yaygınlığı en yüksek olan madde \%16,1'le sigaradır. Bunu alkol \%4,9'la, esrar \%2,'le, uçucu maddeler \%1,4'le takip etmektedir (Çakır, 2011, s. 36). Bizim çalışmamızda madde kullanım sıklı̆̆ daha düşük bulunmuştur.

Edirne'deki araştırmanın 2011 yılında yapıldığı göz önüne alındığında, 2016 yılındaki bizim çalışmamızdaki sigara hariç diğer tüm narkotik maddelerin kullanım oranlarının düşük olmasının sebebi, bu alanda yapılmış olan araştırma yöntemlerindeki farklılıklar, iller arası sosyal ve kültürel yapı farklılıkları, bu alanda alınan tedbirler ve bağımlılığa karşı oluşan farkındalığın artmasından kaynaklanmaktadır.

Amerika'da, '12-17 yaşları arasındaki ergenlerde sigara, alkol ve yasadışı ilaç kullanımı' raporuna göre: Sigara kullanım oranları kadınlarda \%39, erkeklerde \%40; alkol kullanım oranı erkeklerde 38\%, kadınlarda \%40; esrar kullanım oranları erkelerde \%20, kadınlarda \%23 olarak bulunmuştur (Fryar, Merino, Hirsch ve Porter, 2009, s. 1-23). Bizim çalışmamızda madde kullanım oranları kadın ve erkekler arasında yaklaşık olarak benzer olup sigara, alkol ve esrar kullanımı kadınlara oranla erkeklerde anlamlı olarak daha yüksek bulunmuştur.

2009 yılı Avrupa Madde ve Madde Bağımlılı̆̆ İzlem Merkezi (EMCDDA) verilerine göre, 15-24 yaşları arasında hayat boyu esrar kullanımı erkek öğrencilerde kız öğrencilerine oranla en az iki katı olduğu bildirilmiştir (EMCDDA, 2009, s. 11-16). Bizim çalışmada ise esrar kullanımı erkekler öğrencilerde kız öğrencilerine oranla yaklaşık 6 kat daha yüksek bulunmuştur. $\mathrm{Bu}$ durum, bölgenin sosyal ve kültürel husussiyetlerine bağlı olabileceği düşünülmektedir.

'Amerikalı Ergenlerde Madde Kullanımı İle İlgili Geleceğin İzlenmesi' 2010 yılı Raporları'nda; alkol kullanımı 10.Sınıfta \%59,1, 12.sınıfta \%72,3; sigara kullanımı 10.sınıfta \%32,7, 12.sınıfta \%43,6 olarak bulunmuştur. Diğer madde kullanımıları: Esrar 10.sınıfta $\% 32,3$, 12. sinıfta \%42; uçucu maddeler 10. sinıfta \%12,3, 12. sinıfta \%9,5 olarak belirtilmiştir (Johnston, O’Malley, Bachman ve Schulenberg, 2010, s. 31-41). Bu araştırmada madde kullanım nibetleri bizim araştırmamıza kıyasla yüksek olup madde kullanım oranları lise 10. sınıf öğrencilerine oranla lise 12. sınıf öğrencilerinde anlamlı olarak daha yüksektir. 
Araştırmamızda görülen bu farklılıklar, madde kullanım oranlarının yaşla birlikte artış gösterdiği yönündeki diğer araştırmalarla uyumludur.

2014'deki bir çalışmada en fazla sigara içen grup arkadaşlarıyla birlikte kalanlar arasında olup, arkadaşları ile birlikte kalan öğrenciler diğerlerine göre 3,5 kat daha fazla sigara içmekteydi. öğrencilerin öğrenimleri süresince kaldıkları yer sigara içme davranışlarını etkilemekteydi. Öğrencilerden \%42,3’ü sigarayı dükkândan veya sokak satıcısından temin etmiştir; \%79,3'ü yaşının küçük olması nedeniyle sigara satılmaması durumuyla karşılaşmadığını belirtmiştir (Karakaş, Özer, Sazak, 2014, s. 15401-541; Taşdemir, Eker, Kitapçı, Topçu, 2014, s. 1560). Bizim araştırmamızda çalışmaya katılıp da sigara ve alkol dışında herhangi bir madde kullanımı olan öğrencilerin bunu nasıl temin ettiğini belirten öğrencilerden \%68,2 öğrenci maddeye ulaşmakta hiç zorluk çekmediğini belirtmiştir. Hayat boyu en az bir kere madde kullanımı olan öğrencilerin, kullandıkları maddeyi nasıl temin ettiklerine dair; \%52,3'ü en fazla arkadaşlarından; öğrencilerin \%19,6'1 ikinci sıklıkta madde satıcılarından, \%11,2'i ise sevgiliden temin ettiklerini bildirmişlerdir. 2014 yılında yapılan çalışmayla bizim çalışmamız göz önüne alındığında, çalışmamızdaki narkotik maddeleri teminde ulaşılabilirlik düzeyi oranlarının düşük olduğu ve bunun sebebinin, bölgeler arası sosyal ve kültürel yapı farklılıklardan olduğu düşünülmektedir.

$\mathrm{Bu}$ araştırmamızda sigara, alkol ve narkotik madde kullanımı bakımından riskli bir dönem olan lise çağı öğrencileri değerlendirmeye alınmıştır. Araştırma ferdlerin kendilerinin doldurduğu anket formlarıyla yapılmıştır. Bu durum ise bazen verilerin güvenilirliği açısından bir kısıtlılık oluşturmaktadır. Çalışmaya Van İl Merkezinin 25 Lise 10. ile 12.sınıf öğrencileri dahil edilmiştir. Burada amaç olarak yaş dağılımları birbirine yakın olan öğrenciler hedeflenmiştir. İlgili kurum ve kuruluşların çalışmamızın bulgularına bakarak, narkotik madde kullanımı bakımından gençlik çağı risklerini azaltmak için bölgemizde, hususan kullanım oranları yüksek olarak tespit edilen alkol, sigara, esrar ve diğer narkotik madde kullanımına dair farkındalığı arttıracak önlemlerin alınması önem arz etmektedir.

\section{Sonuç}

$\mathrm{Bu}$ araştırma Van İl Merkezinde 25 lise 10. ile 12.sınıf öğrencilerinde; sigara, alkol ve narkotik madde kullanımının yaygınlığı, sigara, alkol ve narkotik madde kullanım oranlarının karşılaştırılmasıdır. Sigara, alkol ve narkotik madde kullanımını etkileyen risk faktörlerinin belirlenmesi amaçlanmıştır. Buna dair çalışmaya 2814 lise öğrencisi alınmış olup;

Year 4/ 2020, Volume-4, Issue-3 | www.ispecjournal.org 
-Lise öğrencileri yaşam boyu en az bir kere madde kullanım oranlarına göre sınıflandırıldığında: Sigara \%29,3 (824 kişi), Alkol \%7,6 (214 kişi), esrar \%3,6 (100 kişi), ekstazi \%1,5 (43 kişi), tiner-bali \%2,9 (82 kişi), akineton \%0,9 (26 kişi), kokain \%1,5 (42 kişi), eroin \%1,3 (36 kişi), amfetamin \%0,9 (25 kişi), captagon \%0,9 (25 kişi), yeşil reçete $\% 1,1$ (32 lişi), diğer madde kullanımı \%0,7 (20 kişi) oranlarında kullanım olduğu bulunmuştur. Çalışmada;

-.Lise 10.sinıf ögrencilerinde: Sigara \%13,1, alkol \%2,7, esrar \%1,5, ekstazi \%0,7, tiner-bali $\% 1,5$, Akineton $\% 0,5$, kokain $\% 0,8$, eroin $\% 0,8$, amfetamin $\% 0,5$, captagon $\% 0,5$, Yeşil Reçete \%0,6, Diğer Madde kullanımı \%0,4 kullanım oranlarında olduğu;

.Lise 12.sını ögrencilerinde: Sigara \%16,1, alkol \%4,9, esrar \%2,0, ekstazi \%0,8, tiner-bali $\% 1,4$, akineton $\% 0,4$, kokain $\% 0,7$, eroin $\% 0,5$, amfetamin $\% 0,4$, captagon $\% 0,4$, Yeşil Reçete, \%0,5, Diğer Madde kullanımı \%0,4 kullanım oranlarında olduğu tespit edilmiştir. Lise 12.sınıf öğrencilerinde lise 10.sınıf öğrencilerine oranla sigara, alkol ve esrar kullanım oranları anlamlı olarak daha yüksek bulunmuştur.

- Başta sigara, alkol ve esrar olmak üzere diğer tüm narkotik madde kullanım oranları kızlara göre erkeklerde anlamlı olarak daha yüksek olduğu tespit edilmiştir.

- Lise Okul Türlerinde: Madde Kullanım sıklığı öğrenciler arasında en çok kullanılan maddeler \%29,3'le sigaradır. Bunu alkol \%7,6, esrar \%3,6, tiner-bali \%2,9'le ile ekstazi \%1,5 olarak takip etmektedir. Okul Türlerine göre öğrencilerden hayat boyu en az bir kere madde kullanımını işaretleyenler total 2814 kişi olup kullandığını belirten \%30,5 (858 kişi), kullanmadığını belirten \%69,5 (1956 kişi) olarak bulunmuştur. Özelde, Lise Türleri arasında Genel Liseler (Genel-Anadolu-Fen) ile meslek (Endüstri-İmam Hatip-Güzel Sanatlar ve Spor) liseleri öğrencilerindeki yhayat boyu en az bir kere madde kullanım oran ve dağılımları ise: Fen Lisesi \%25, Meslek Liseleri 30,2\%, Anadolu Lisesi 31,0\%, olarak bulunmuştur. Totalde ise, lise öğrencileri hayat boyu en az bir kere madde kullanım oranlarına göre sınıflandırıldığında: Fen Lisesi \%0,7 (19 kişi), Meslek Lisesi \%14,1 (397 kişi) Anadolu Lisesi \%15,7 (442 kişi) olarak belirlenmiştir.

- Araştırmaya katılıp da Narkotik Madde kullanan öğrencilerden bunu temin etmesine dair; sigara ve alkol dışında herhangi bir madde kullanımı olan öğrencilerin bunu nasıl temin ettiğini belirten öğrencilerden \%68,2 öğrenci maddeye ulaşmakta hiç zorluk çekmediğini belirtmiştir. Yaşam boyu en az bir kere madde kullanımı olan öğrencilerin, kullandıkları maddeyi nereden temin ettiklerine dair; öğrencilerin \%52,3’ü en fazla arkadaşlarından, 
\%19,6'1 ikinci sıklıkta madde satıcılarından, \%11,2'i ise sevgiliden temin ettiklerini bildirmişlerdir.

Öğrencilerin narkotik maddeleri teminde kolay ulaşılabilir olmaları, madde kullanım oranlarının anlamlı olarak daha yükselmekte olduğu görülmektetir.

\section{6. Öneriler}

Narkotik Madde Kullanımı probleminde Avrupa ülkeleri, ABD ve Türkiye karşılaştırıldığında Türkiye'de çok ileri derecede olmamakla beraber hızlı bir artış halindedir. Van İlinde de Türkiye'nin batı kentlerine nisbetle aynı şekilde Narkotik Madde Kullanım Problemi daha düşük seviyelerdedir. Lakin bu bölgede de hızlı bir artış söz konusudur. Hem Türkiye ve hemde Van İli bazındaki artış hızı gelecekte kritik sosyal problemlere neden olacaktır. Gerçi Narkotik Madde Bağımlılı̆̆ı dünyada ve Türkiye'de giderek yaygınlık kazanmakta ve olumsuz sonuçlarıyla geleceği tehdit etmektedir, fakat yine de Türkiye'nin henüz kontrolü elden kaçırmamış olmasından, yapılabilecek daha çok şeyleri vardır.

Bütün dünyada narkotik bağımlılığını önleme programları ve uluslararası mücadele kurum ve kuruluşlarının işbirliği yapma çalışmaları giderek önem kazandığı günümüzde, sorunların üstesinden gelebilmesi için uluslararası mücadele örgütleriyle de işbirliğine gidilmelidir. Ayrlca;

-Liseye başlama, narkotik madde kullanımında yaş ve arkadaş özellikleri bakımından kritik bir çağdır. Bundan dolayı gençlere yönelik yapılan koruma ve önleme çalışmaları lise başlangıcında daha çok uygulanmalıdır. $\mathrm{Bu}$ yaş grubu genclerin arkadaş ve akranlarıyla birlikte boş zamanlarını iyi değerlendirecekleri faaliyetlere daha çok firsatlar oluşturulmalı; sigara, alkol ve narkotik madde kullanımının tehlikeleri konusunda farkındalıkları arttırılıp öğrencilerin teşkil edecekleri sosyal kulüplerde akran eğitimine imkan ve ortamlar sağlanmalıdır.

-Sigara ve alkol kullanımı narkotik madde kullanımına geçiş basamağı olduğundan bunların üzerinde önemle durulmadır.

-Reklamların halk üzerindeki tesiri göz önünde bulundurularak, reklamlar ve sosyal programlara sponsor olan örgütlerin yayınlattıkları reklamlarına dikkat edilmeli, ülke çapında önlemler alınmalıdır.

-Narkotik maddelerin gerek ulusal ve gerekse uluslararası kaçakçılık ve ticaretini engellemek, kontrol altına almak ya da yok etmek adına, mevcut ulusal ve uluslararası düzeyde milli 
kalkınma planlarında konuya yer verilmeli, bu mücadele örgütleriyle tam bir ciddiyet, samimiyet, duyarlılık ve kararlılıkla işbirliği yapmalı ve daha sıkı koordinasyonlar içine girilmelidir.

-Umumiyetle araştırma alanımız olan narkotik madde kullanımı konusunda yapılan çalışmalar, yurtdışında ya da yurtiçinde yapılan diğer araştırmalara göre daha düşük düzeyde olmasından, bu alanda daha çok çalışma yapılmalıdır.

Netice şu ki:

$\mathrm{Bu}$ araştırmanın ortaya koyduğu en önemli netice; zamanın ve sosyal faaliyetlerin, madde kullanımı gibi riskli davranışlar üzerindeki olumlu ya da olumsuz etkilerinin yapılan bu araştırmayla taranmış olması faydasıdır. Araştırma alanımız olan Van İlindeki sonuçlar sevindirici düzeyde düşük olmasıdır. Ancak problem hiç yok değildir, bundan sonra da bu konuda böylesi tespit çalışmalarının periyodik olarak devam ettirilmesi ve çözümlere dair tekliflerin güncellenmesi gerekmektedir.

\section{Kaynakça}

Ağırakça, A. (2000). Şamil İslam Ansiklopedisi. C.VIII. İstanbul: Şamil Yayınları.

Akbulut, İ. (1997). Ülkemizde uyuşturucu maddeler sorunu. İstanbul Üniversitesi Hukuk Fakültesi Mecmuası (İHFM), 55(3), 111-142.

Asan, Ö., Göka, E., Okay, İ. T., Tıkır, B. (2015). Bir AMATEM birimine başvuran alkol ve madde kullanım bozukluğu olan hastaların sosyodemografik ve klinik özellikleri. Bă̆ımlılık Dergisi, 16(1), 1-8.

Balcı, A. (2015). Sosyal Bilimlerde Araştırma Yöntem Teknik ve İlkeler. Ankara: Pegem Akademi Yayınları.

Baygal. A. (2009). Alkol ve uyuşturucu madde bağımlılı̆̆ı. Nurşen ADAK (Ed.). Sosyal Problemler Sosyolojisi Dünyadan ve Türkiye'den Örnekler içinde (s. 249-285). Ankara: Desen Ofset A.Ş

Buğdaycı, G. (2008). Üniversite öğrencilerinin sigara alkol ve madde kullanımı ve madde kullanımını etkileyen sosyal kültürel ve ekonomik süreçler: Sakarya üniversitesi örneği. (Yayınlanmamış Yüksek Lisans Tezi). Sakarya Üniversitesi Sosyal Bilimler Enstitüsü.

Büyüköztürk, Ş., vd. (2014). Bilimsel Araştırma Yöntemleri Ankara: Pegem Akademi Yayınları. 
Çakır, D. (2011). Edirne'deki liselerde ve Trakya Üniversitesi öğrencilerinde alkol ve psikoaktif madde kullanımının yaygınlığı. (Uzmanlık Tezi). Trakya Üniversitesi Tıp Fakültesi Ruh Salığı ve Hastalıkları ABD.

Demirhan, H. (1999). Denizli İli, Tavas İlçe merkezinde yer alan ortaöğrenim öğrencilerinde sigara, alkol ve uçucu madde kullanımı. (Yayınlanmamış Yüksek Lisans Tezi). Pamukkale Üniversitesi Sağlık Bilimler Enstitüsü, Halk Sağlığı A.B.D.

Dökmeci, G., Saltık, A., Dökmeci, İ. (1990). Edirne merkezinde halkın uyuşturucu ve nonmedikal ilaç kullanımı epidemiolojisi. Trakya Üniversitesi Tip Fakültesi Dergisi, (5.6.7 (Bileşik Say1)), 93-103.

Dönmezer, S. (1981). Kriminoloji. İstanbul: İstanbul Üniversitesi Yayınları.

EMCDDA (2009). Avrupa'da uyuşturucu sorununun durumu hakkındaki 2009 Yıllık raporu, Lizbon. EMCDDA, Kasım 2009. Lüksemburg: Avrupa Toplulukları Resmi Yayınlar Bürosu, 2009 ISBN 978-92-9168-400-7

Ergenç, G., Yıldırım, E. (Ed.) (2007). Madde kullanımı önleme klavuzu. İstanbul: https://docplayer.biz.tr/332106-Madde-kullanimi-onleme-klavuzu.html

ESPAD (2007). Substance Use Among Students in 35 European Countries, Stockholm,

Retrieved January 8, URN:NBN:se:can-2009-2

Evcin, U. (2011). Lise gençlerinin vakit geçirdiği ortamların madde kullanımı davranışı üzerindeki etkileri: Bayrampaşa Örneklemi. (Yayınlanmamış Yüksek Lisans Tezi). İstanbul Üniversitesi Adli Tıp Enstitüsü, Sosyal Bilimler Anabilim Dalı.

Fryar, CD., Merino, MC., Hirsch, R., Porter, KS. (2009). Smoking, alcohol use, and illicit drug use reported by adolescents aged 12-17 years: United States, 1999-2004. Natl Health Stat Report, (15):1-23. https://doi.org/10.1037/e623962009-001

IŞIK, H. (1982) Evrensel boyutlarıly Uyuşturucu Madde ve Kaçakçılık Sorunu, Bunların Ulusal ekonomi ve Ulusal Güvenliğe etkileri. Genelkurmay Askeri Tarih ve Stratejik Etüt Başkanlığı yayınları. Güncel konular serisi, 8(3), 39-55.

Işık, M. (2013). Madde Kullanımı ve Stratejik İletişim. Ankara: SAGE Yayıncılık.

Johnston, LD., O’Malley, PM., Bachman, JG., Schulenberg, JE. (2010). Monitoring the future national results on adolescent drug use: Overview of key findings, 2010. (NIH Publication No.10- 7585). Bethesda, MD: National Institute on Drug Abuse. 
Karakaş, N., Özer, A., Sazak Y. (2014) Sağlık hizmetleri meslek yüksek okulu öğrencilerinin sigara içme davranışları ve etkileyen faktörlerin incelenmesi. 17. Ulusal Halk Sağlı̆̆ Kongresi'inde sunulan bildiri, Trakya Üniversitesi Tıp Fakültesi Halk Sağlığı ABD, Edirne.

Karataşoğlu, S. (2013). Sosyal politika boyutuyla madde bağımlılığı. Türk Idare Dergisi, Sayı: 476. Ankara: İçişleri Bakanlığı Yayınevi.

Ögel, K. (2001) İnsan, Yaşam ve Bağımlılık. İstanbul: IQ Kültür Sanat Yayıncılık.

Ögel, K. (2005). Madde kullanım bozuklukları epidemiyolojisi. Türkiye Klinikleri J Int Med Sci., I(47), 61-64.

Ögel, K., Çorapçığlu, A., Doğan, O., Sır, A., Tamar, M., Tot, Ş. ve ark. (2004). Türkiye'de dokuz ilde ilk ve ortaöğretim öğrencilerinde tütün, alkol ve madde kullanım yaygınlığı. Türk Psikiyatri Dergisi, 15:112-8.

Ögel, K., Ermağan, E., Eke, C. Y. ve Taner, S. (2007). Madde deneyen ve denemeyen ergenlerde sosyal aktivitelere katılım: İstanbul örneklemi. Bă̆ımlılk Dergisi, 8(1), 18-23.

Ögel, K., Tamar, D., Evren, C., Çakmak, D. (2000). İstanbul'da lise gençleri arasında sigara, alkol ve madde kullanım yaygınlığı. Klinik Psikiyatri, 3: 242-245.

Ögel, K., Taner, S., Eke, C. Y. (2006). Onuncu sınıf öğrencileri arasında tütün, alkol ve madde kullanım yaygınlığı: istanbul örneklemi. Bă̆ımlılık Dergisi, 7(1), 18-23.

Sadock BJ. (2007) Maddeye Bağlı Bozukluklar. "Kaplan \& Sadock's Comprehensive Textbook of Psychiatry”, Sekizinci Baskı. Aydın H, Bozkurt A (editörler). İstanbul Güneş Kitabevi. s.1137-1318.

Sevil, H. T. (1998). Uyuşturucu Bağımlılı̆̆ı Tanımlar Sorunlar Çözümler. Ankara: SABEV Yayınlar1.

Soysaldı, M. (2007). Gençliğimizi tehdit eden zararlı alışkanlıklar: Sigara, alkol ve uyuşturucu. ISSN: 1306-3111 e-Journal of New World Sciences Academy, 2(2) Article Number: C0006.

Taşdemir, M., Eker, H. H., Kitapçı, N. Ş., Topçu, İ. (2014) Ulusal ha lk sağlığı kongresi beyoğlu ilçesinde bulunan 9. sınıf öğrencilerinin tütün kullanımıyla ilgili bilgi, tutum, davranış ve değerlendirmeleri. 17. Ulusal Halk Sağlığı Kongresi'inde sunulan bildiri, Trakya Üniversitesi Tıp Fakültesi Halk Sağlı̆̆ı ABD, Edirne

Tuncer, A. (2011). Uyuşturucu veya Uyarıcı Madde Ticareti ve Kullanılmasına İlişkin Suçlar. (Yayınlanmamış Doktora Tezi). Ardahan Üniversitesi Sosyal Bilimler Enstitüsü. 
Ünlü, A., Evcin, U. (2010). İstanbul'da liseli gencler arasındaki madde kullanım yaygınlığ ve demokrafik faktorlerin etkileri. Literatür Sempozyum Dergisi, 5.

Yıldız, E.U. (2009). İzmir Liselerinde Sigara, Alkol, Madde Kullanım Yaygınlı̆̆ Hazırlayıcı ve Koruyucu Faktörler. (Yayınlanmamış Doktora Tezi). Ege Üniversitesi Sosyal Bilimler Enstitüsü. 